\title{
Working
}

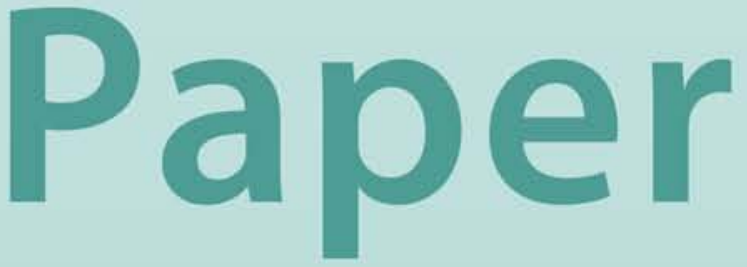


Bidding Behavior in Treasury Bill Auctions:

Evidence from Pakistan

Daniel C. Hardy 


\title{
IMF Working Paper
}

Middle Eastern Department

\section{Bidding Behavior in Treasury Bill Auctions: Evidence from Pakistan}

Prepared by Daniel C. Hardy ${ }^{1}$

Authorized for distribution by Antônio Furtado

June 2000

\begin{abstract}
The views expressed in this Working Paper are those of the author(s) and do not necessarily represent those of the IMF or IMF policy. Working Papers describe research in progress by the author(s) and are published to elicit comments and to further debate.
\end{abstract}

Behavior in the first three years of auctions for Pakistani treasury bills is studied. Bidding strategies rapidly converged to a consistent pattern after the auctions started in 1991. Factors are identified that influenced the expected profitability of auction participation, which was on average low and did not differ between types of bidders. Prices bid are found to reflected both 'buy and sell' and 'buy and hold' strategies, and were affected by risk considerations and bidder-specific variables. The Pakistani experience suggests the robustness of auctions as a market-based allocation mechanism, and their value in public debt management.

JEL Classification Numbers:D44, G14, H63, O16

Keywords: auctions, Pakistan, treasury bills

Author's E-Mail Address: dhardy@imf.org

\footnotetext{
'Middle Eastern Department, International Monetary Fund. This paper would not have been possible without the assistance of Syed Ali Sultan, who kindly supplied the data, and of Peter Dattels, who provided much advice and cooperated on an earlier version. William Alexander, Antônio Furtado, and Aasim Husain offered helpful comments.
} 
Contents Page

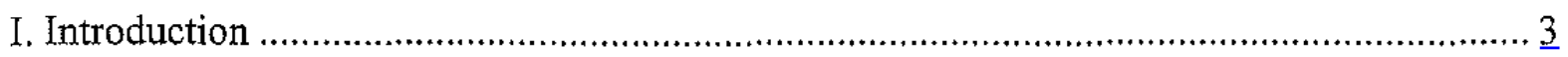

II. Development of the Government Securities Market in Pakistan .................................. 4

Financial sector reform in Pakistan................................................................... 4

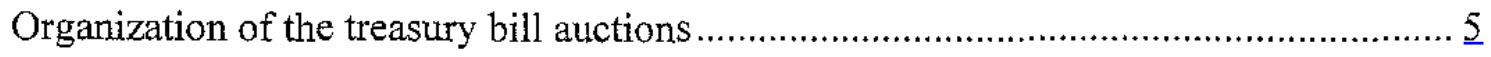

III. Sample Characteristics .................................................................................... 6

Data set and definitions...............................................................................

Characteristics of the auctions and bidding behavior ........................................... $\underline{8}$

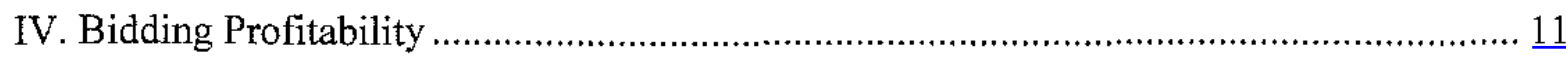

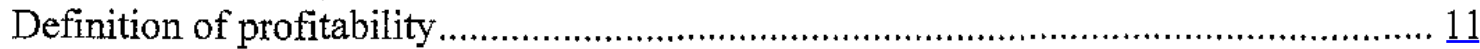

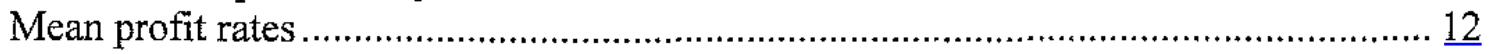

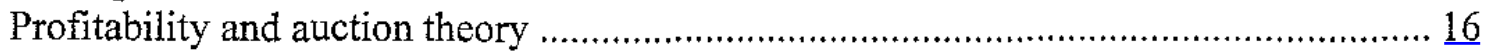

Specification of regressions on profitability .................................................. 18

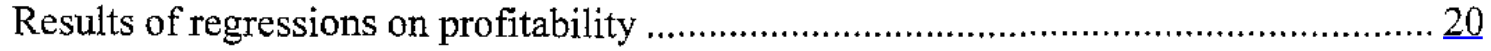

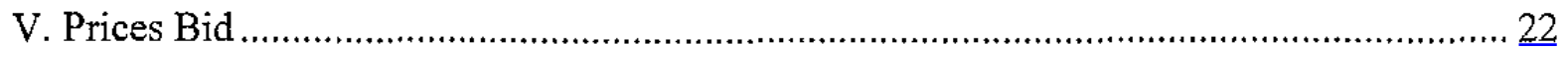

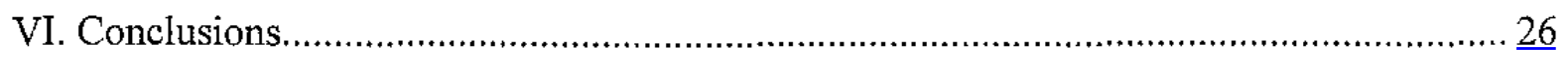

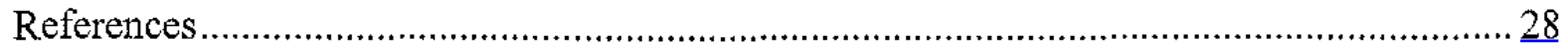

\section{Tables}

1. Bidding Behavior and Profitability by Bank ....................................................... 15

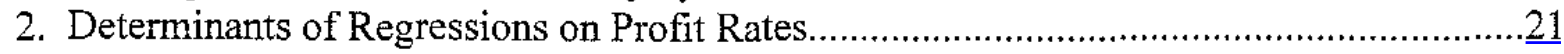

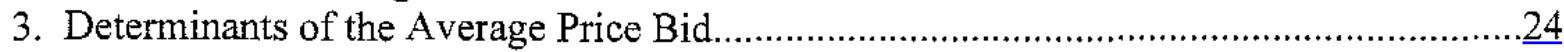

Figures

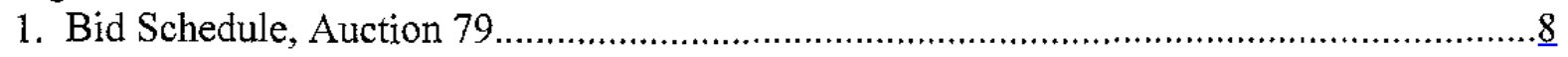

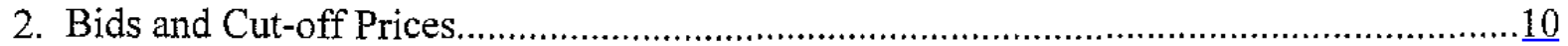

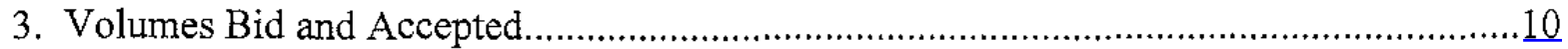

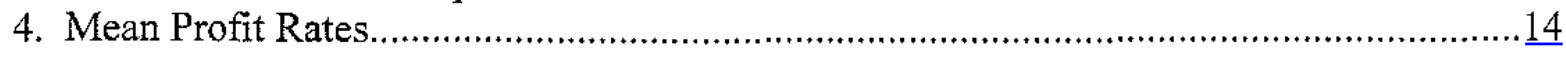

Appendix I

Summary of Variables Employed........................................................................ 


\section{INTRODUCTION}

Auctions represent a paradigm example of a market-based mechanism for the allocation of resources, albeit one characterized by asymmetric information and imperfect competition, and they have therefore long attracted the attention of economists. A large body of theoretical literature has addressed such issues as the revenue equivalence of different auction forms, optimal auction design, and the efficiency of the allocation generated by auctions or similar mechanisms. ${ }^{2}$ A smaller but still substantial body of literature attempts to test the implications of these theories, often using data from auctions for mineral rights or construction contracts, or from experiments; empirical studies of the applicability of auction theory to the market for government securities are rarer and mostly recent. ${ }^{3}$ The present paper is meant first to contribute to the empirical literature on how auction-like mechanisms function in practice.

In monetary terms some of the most important auctions are those for government securities. Trillions of dollars worth of government securities are auctioned every year, and in many countries the cost of funding the government deficit, and thus intertemporal trade-offs faced in the public sector, is determined by auction. Over the last twenty years, auctions for government securities have become common not only in the industrialized countries, but also in developing and transition countries as diverse as Jordan, the Czech Republic, Kenya, Mexico, and of course Pakistan. A second aim of this paper is to provide evidence on the functioning of a system of government securities auctions in general, and in particular those that have been newly established in developing countries.

For Pakistan the introduction of a regular series of treasury bill auctions was part of a wideranging program of financial sector liberalization, and a move away from traditional, nontransparent means of government debt management towards a market-based approach. The third aim of this paper is to assess whether the auctions in some sense worked well for Pakistan, or whether they raised the cost of government borrowing unnecessarily or otherwise functioned unsatisfactorily.

After this introduction, the second section provides background on Pakistan's financial sector reform program that started in the early 1990s, and the institutional arrangements for the treasury bill auctions. The third section describes the data set and presents some stylized facts about the evolution of the auctions. In section four, the profitability of participating in the auctions is estimated so as to establish the average cost to the government of conducting the auctions, and profitability is compared across bidders to detect evidence of abnormal returns.

${ }^{2}$ Useful surveys include McAffie and (1987) and Milgrom (1989). Bikhchandani and Huang (1993), Bartolini and Cottarelli (1994) and Das and Sundaram (1996) review the application of auction theory to government securities markets.

${ }^{3}$ See Cammack (1979), Spindt and Stolz (1992), Umlauf (1993), and Simon (1994). 
Profitability rates are then related to explanatory variables suggested by auction theory. The fifth section looks at the average prices bid and presents an attempt to identify their determinants, before the last section concludes.

\section{Development of the Government Securities Market in Pakistan}

\section{Financial sector reform in Pakistan ${ }^{4}$}

For most of the period since independence, the Pakistani financial system had been subject to direction and control by government. All commercial banks in Pakistan were nationalized in 1974 , and a system was instituted to channel funding to priority areas of development at controlled interest rates. The Pakistani government relied on a variety of complex instruments and regulations to mobilize savings to finance the government deficit and public sector development projects. The true cost of public borrowing was obscured: the administrative control of interest rates, and the compulsory aspects of the financing, such as liquid asset requirements on commercial banks and controls on overseas investment, tended to place a hidden burden on borrowers and the commercial banks; ${ }^{5}$ the favorable tax treatment of the numerous savings schemes directed at households resulted in an unmeasured revenue loss. Treasury bills were available, but they were sold on tap at a fixed interest rate. The situation was sustainable because domestic financing needs were limited; fiscal deficits were usually contained, and Pakistan could obtain foreign loans and other assistance.

By the mid-1980s this heavily regulated and state-dominated system began to seem less satisfactory. It was increasingly felt that incentives for saving (and for the remittance of savings from the large Pakistani community abroad) were inadequate, and that resources were not being allocated to the most productive uses. In addition, the traditional approach to public debt management was placed under increasing strain by the government's rising need for domestic financing. ${ }^{6}$ In response, a program of domestic financial sector liberalization

\footnotetext{
${ }^{4}$ Khan and Aftab (1994) and U1 Haque (1997) provide a more extensive overview of the financial sector in Pakistan and its reform over the past decade.

${ }^{5}$ In addition the government could borrow from the central bank, the State Bank of Pakistan (SBP), at an interest rate of 0.5 percent, thus passing the cost on to that institution.

${ }^{6}$ Total federal government debt had increased from 61 percent of GDP in 1985 to 74 percent of GDP in 1990, and domestic government debt rose from 31 percent of GDP to 42 percent of GDP. Over the same period, the total balance in the savings schemes grew from 12 percent of GDP to 17 percent of GDP, the largest single component of federal government domestic debt and about three times that held by commercial banks. By 1990, debt servicing absorbed 39 percent of all government expenditure (State Bank of Pakistan, Annual Report, various issues).
} 
was launched in 1990-91. The establishment of private banks was permitted in 1990, foreign banks were allowed to engage in more domestic business, and over time a number of state-owned banks were privatized. Interest rates were liberalized and credit ceilings dismantled.

In the area of public debt management, the reform program aimed at enhancing the ability of government to finance its operations while ultimately reducing the debt service burden; establishing market-based rates of return on government debt instruments, which would make the cost of government deficit financing transparent; promoting a secondary market in securities; encouraging reintermediation through the banking system; and facilitating the introduction of indirect instruments of monetary policy implementation. A major step in the reform program was the initiation of a regular series of auctions of government securities: starting in February-March 1991, the government began auctioning 6-month bills (the focus of attention in this study), and bonds with maturities of between 3 and 10 years. To promote demand for and secondary market trading in the new securities, the issue of securities on tap and of domestic bearer bonds was discontinued (although foreign currency bonds and bearer certificates were introduced), institutional investment in savings schemes was limited, and the SBP raised its rediscount rate on treasury bills to 10 percent. The liquid asset requirement, however, was retained. At a technical level, the new securities were registered in an electronic book entry system to facilitate trading. The SBP, which acted as the government agent in running the auctions, designated approximately sixty primary dealers from among the commercial banks and other financial institutions, who would bid at the auctions for domestic securities either on their own behalf or on behalf of clients, and who would subsequently trade in securities with each other and distribute them at a retail level. ${ }^{8}$ Since 1991, these market-based instruments have become the major form of domestic government debt. ${ }^{9}$

\section{Organization of the treasury bill auctions}

The auctions of six-month treasury bill were conducted according to procedures in most regards similar to those used in other countries, but with some peculiarities. The auctions, which were held roughly every two weeks, were announced approximately one week in advance. Primary dealers and other bank and nonbank financial institutions were allowed to submit any number of sealed price-quantity bids on their own behalf or on behalf of clients. All auctions were conducted on a discriminatory price basis, so each bid was formulated in

\footnotetext{
${ }^{7}$ Liberalization of the external capital account transactions moved more slowly, and in subsequent years was partially reversed.

${ }^{8}$ Carracedo and Dattels (1997) describe the new debt management system in detail.

${ }^{9}$ By 1993 treasury bonds and bills constituted one half of domestic federal government debt outstanding excluding that to the SBP.
} 
the expectation that, if accepted, the price bid would be that paid. After the deadline for bid submission, the bids were opened in the presence of the bidders; this rather unusual practice allowed all participants to know every bid by bidder. ${ }^{10}$ The Ministry of Finance would decide on the cut-off price after seeing the bids; although notionally the size of the auction issue was preannounced, in practice the cut-off price seems to have been the main decision variable and the amount allocated bore little relation to the preannounced size. The setting of the cut-off price was influenced by a number of factors, of which debt service costs and the need for funding were most prominent. On a number of occasions the authorities decided to reject all bids, in part because they felt the bids were in some sense unreasonably low. This sentiment was expressed by Mr. Mohammad Ilyas, Director of the Securities Department, SBP, who stated that

"Out of 48 treasury bill auctions held up to $1^{\text {st }}$ December, 1992 the Government had to reject all bids in 6 auctions only due to the fact that the bidders had quoted much lower prices which were not compatible with the market conditions."

(Journal of the Institute of Bankers in Pakistan, 1994).

The extra degree of uncertainty created by the authorities' inability or unwillingness to precommit to selling a fixed quantity of bills constitutes a major departure from 'standard' practice in treasury bill auctions. Bidders were aware of this uncertainty (in addition to uncertainty about the aggregate bid schedule) and presumably took it into account when formulating their bidding strategies.

One or two days after the deadline for bid submission, the auction results would be communicated to the participants, and trading in the new bills would begin on a "whenissued' basis. ${ }^{11}$ Settlement would take place three or four days after the bids were submitted, and the when-issued trades would settle at the same time. Thereafter the newly issued or 'on the run' bills would trade normally in the secondary market until the next auction. The participants in the secondary market were essentially the same institutions that participated in the auctions.

\section{Sample Characteristics}

\section{Data set and definitions}

Data was obtained on bidding behavior and outcomes in the first 84 auctions of six-month treasury bills, covering a period from February 1991 to May 1994. The core of the sample is

\footnotetext{
${ }^{10}$ The publication of bids made possible the collection of the data set used in this study.

${ }^{11}$ There does not seem to have been significant when-issued trading before the deadline, as there is for example in the U.S. treasury bill market.
} 
formed by observations of the price-quantity pairs that constituted the bids, each identified by bidder and by auction. After the deletion of a small number of outliers, which mostly seemed to reflect recording errors, ${ }^{12}$ the data set comprised 6506 observations. Data on the cut-off price (designated $C O$ ), the maturity of each bill issue (which varied slightly around a mode of 183 days), and the dates of bid submission and results announcement were also available. ${ }^{13}$ All prices were annualized (harmonizing the maturities at 365 days), and logarithms taken. Then means were estimated by auction and by bidder in each auction, and either unweighted or weighted by the amount bid; below, in examining the prices bid, attention focuses on the weighted mean of the annualized log prices bid by each bidder in each auction $(W M P)$. In addition, the standard errors of the prices bid, both by auction and by bidder by auction, and either weighted or unweighted, were calculated as measures of bid dispersion. Also calculated were the total volume bid, the volume of winning bids, the total value of bids and winning bids for individual bidders (all in levels and in logarithms), the number of participating bidders and successful bidders, and the number of bids.

The data on bidding behavior were complemented by those on secondary market prices. In particular, daily data were obtained on both the bid and offer price for treasury bills quoted in the Karachi interbank market for the period beginning with the twenty-fifth auction, by which time reportedly the secondary market in bills had become fairly liquid. The quotes, which were recorded in the course of the morning when activity was heaviest, apply to whatever bill is "on the run," that is, the most recently issued bill. Thus, the treasury bill offer price up to the morning before the deadline for submission of bids for an auction (designated as $T B O F F(-1))$ represents the price at which a potential bidder could buy bills from the previous issue; the treasury bill bid price on the day when auction results were announced (designated as $T B B I D(+1)$ ) represents the price at which a winning bidder could sell newlyauctioned bills in the when-issued market. The secondary market bid and offer prices were annualized, and logarithms taken. Other secondary market data included the overnight interbank interest rate, which may be taken as a measure of the cost of carry for commercial banks of holding treasury bills.

The principal variables employed are listed in Appendix I, along with summary statistics for the primary sub-sample used subsequently for estimation purposes. Specifically, the subsample excludes the initial period for which no secondary market data are available, a period when the cut-off price was approximately constant, and instances where a bidder submitted just a single bid. Log prices are multiplied by 100 in order to increase the number of significant digits.

${ }^{12}$ In the first auction one bidder submitted two very low priced bids, reportedly because an annualized discount factor had been applied by mistake.

${ }^{13}$ For auctions where all bids were rejected a notional cut-off prices is defined at a level slightly above that of the highest bid received. 


\section{Characteristics of the auctions and bidding behavior}

An examination of the data allows one to discern some of the main features of the auctions and bidding behavior. A typical auction attracted scores of bids from perhaps two dozen bidders, for a total value of about Rupees (Rs) 10 billion, and on average about Rs 4 billion was sold in each auction. A typical bid schedule (taken from auction 79) is shown in Figure 1 , where prices bid are in descending order and the horizontal axis shows the cumulative amount bid in millions of Rupees. The shape of the bid schedule resembles the mirror-image of a cumulative distribution function, with a small value of bids at very high or low prices and most bids being clustered closely around the cut-off.

Figure 1. Bid Schedule, Auction 79

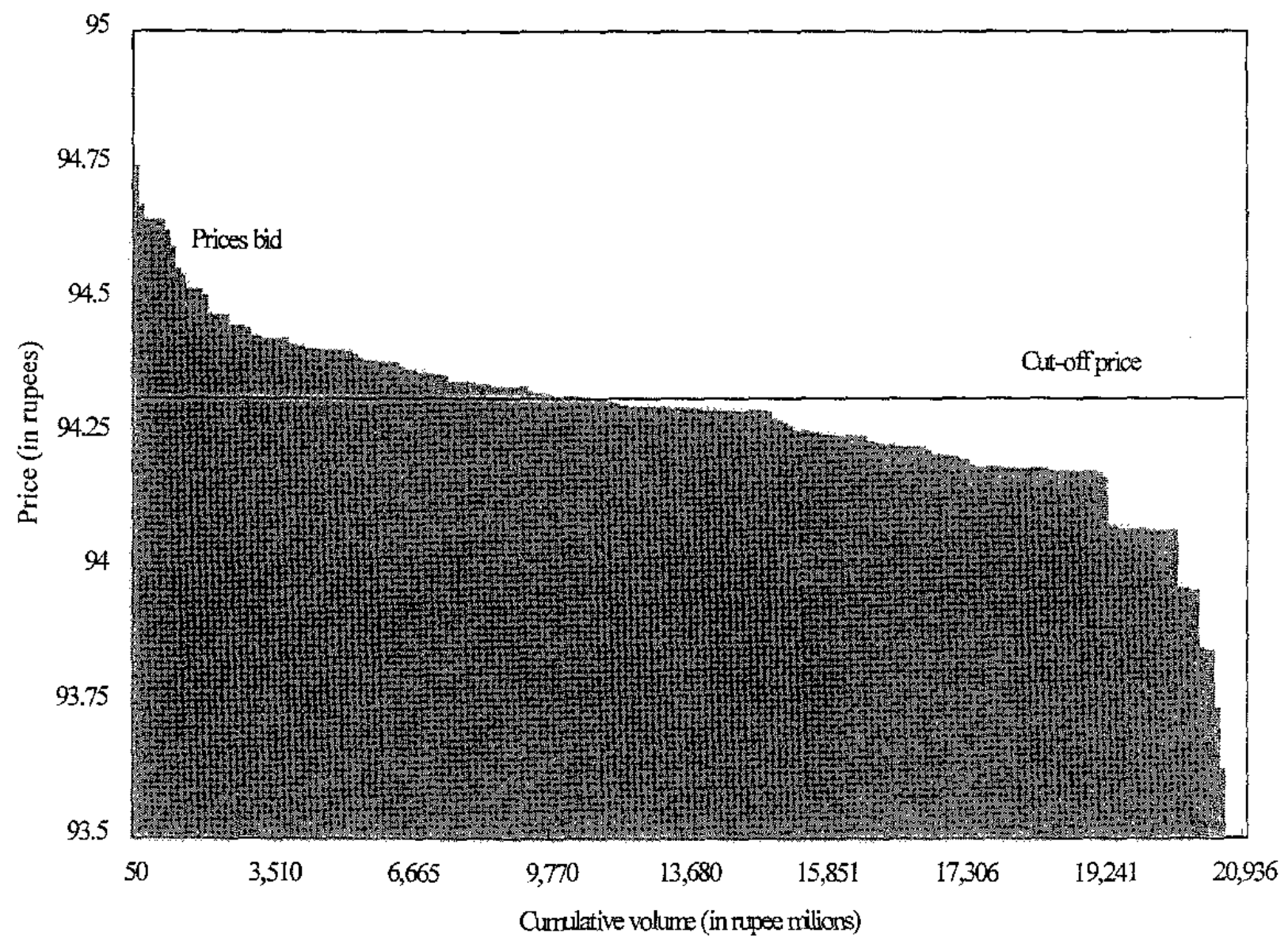


Figure 2 illustrates the evolution of prices over the course of all 84 auctions in the sample. The cut-off price, the weighted mean of the prices bid, and the range of bids are shown. Figure 3 shows the volume of bids and the volume of bids accepted. During the first five or six auctions the range of prices bid was especially great, and the average price bid fluctuated around the cut-off. Presumably during this period participants were experimenting with their bidding strategies and learning to anticipate the strategies of each other and that of the authorities in setting the cut-off price. It is striking, however, that this learning period appears to have been quite short, and convergence to what proved to be typical bidding behavior seems to have been achieved in about three months.

Subsequently, the average price bid was usually slightly below the eventual cut-off price, and the range of bids was typically equivalent to about 80 basis points. Much of the variation that did occur seems to have originated from the authorities, such as on those occasions when they rejected all bids (auctions 16, 19,35, 45, 46 and 48). During a period from auction 45 through 62 the authorities allowed very little fluctuation in the cut-off price. As seen in Figure 2, that period saw a narrowing of the range of bids received, which also became more asymmetric, with a relatively long 'tail' of low bids and few bids significantly above the cutoff; presumably participants expected that any large deviation from the fixed cut-off price would be downward. Figure 3 illustrates that the volume of bids received and especially the amount allocated decreased sharply during this period, which indicates that the cut-off price had been fixed at too high a level to sustain the previous level of funding.

The time-series properties of the series were reviewed. Most series displayed strong autocorrelation at lag 1 , and often some correlation at lags 2 and 6 . The serial correlation at lag 6, which, with bi-weekly auctions corresponds to approximately a quarter year, may be the product of underlying seasonal influences in the Pakistani economy, notably the agricultural cycle and the quarterly payment of some taxes, including certain taxes on commercial banks.

The hypothesis of non-stationarity of the aggregate price series could not be rejected in augmented Dickey-Fuller tests. Changes in the cut-off price, the average price bid, and secondary market prices seem to be very persistent, as is common in financial market pricing. ${ }^{14}$ The possibility of non-stationarity was taken into account in estimation by subtracting the previous cut-off price from all prices (all in logarithms); the hypothesis of non-stationarity could be rejected for the differenced series. ${ }^{15}$

${ }^{14}$ The prices of the bills need not follow a random walk to be non-stationary or sufficiently close to non-stationary to present estimation issues in the limited sample available.

${ }^{15}$ The previous cut-off price should be well known to market participants when they prepare their bids and in secondary market trading immediately before each auction. Individually differencing each series, including the average bid by bidder, would be problematic given the panel structure of the data set, especially because many bidders participated only sporadically. 
Figure 2. Bids and Cut-off Prices

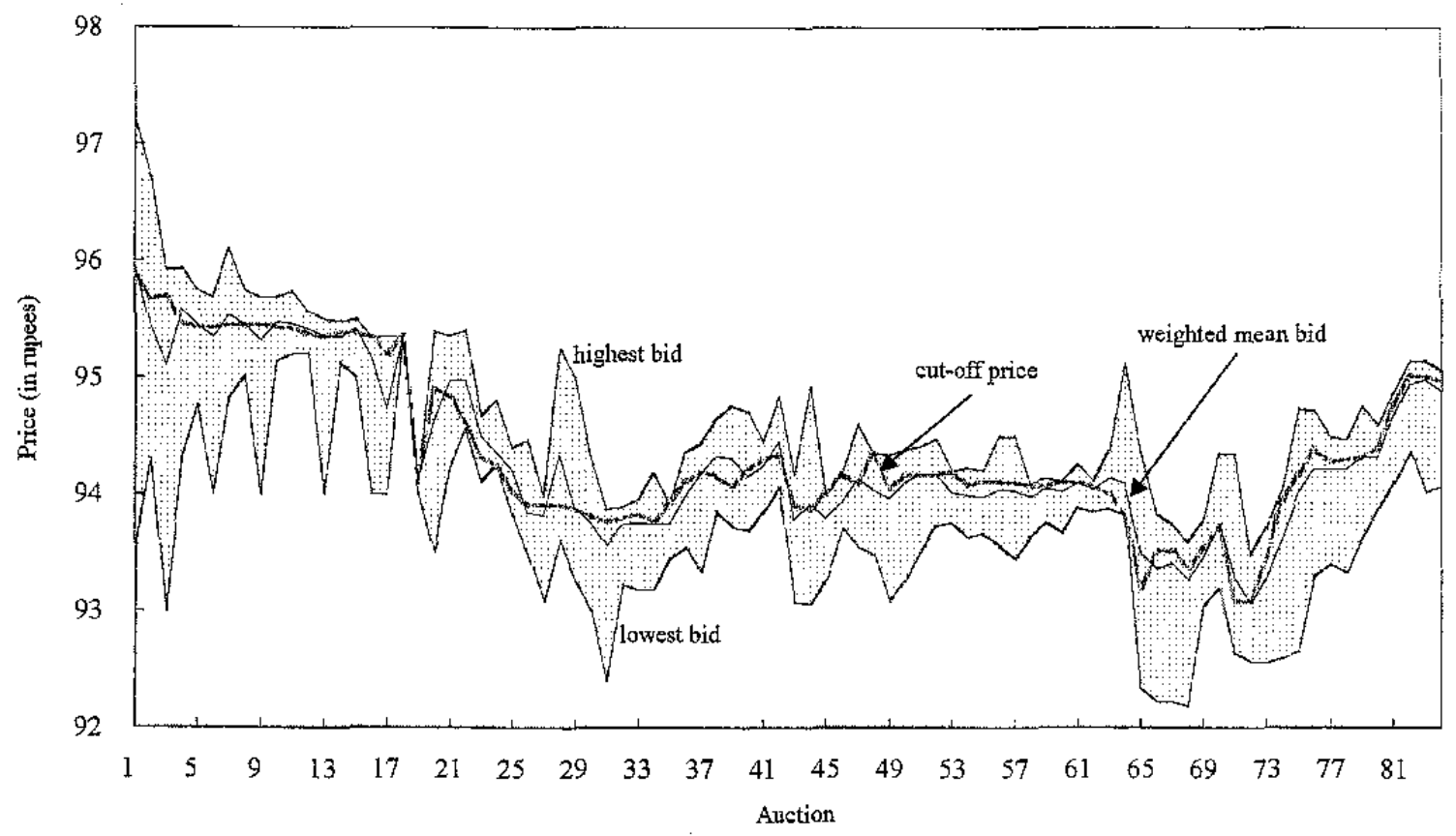

Figure 3. Volumes Bid and Accepted

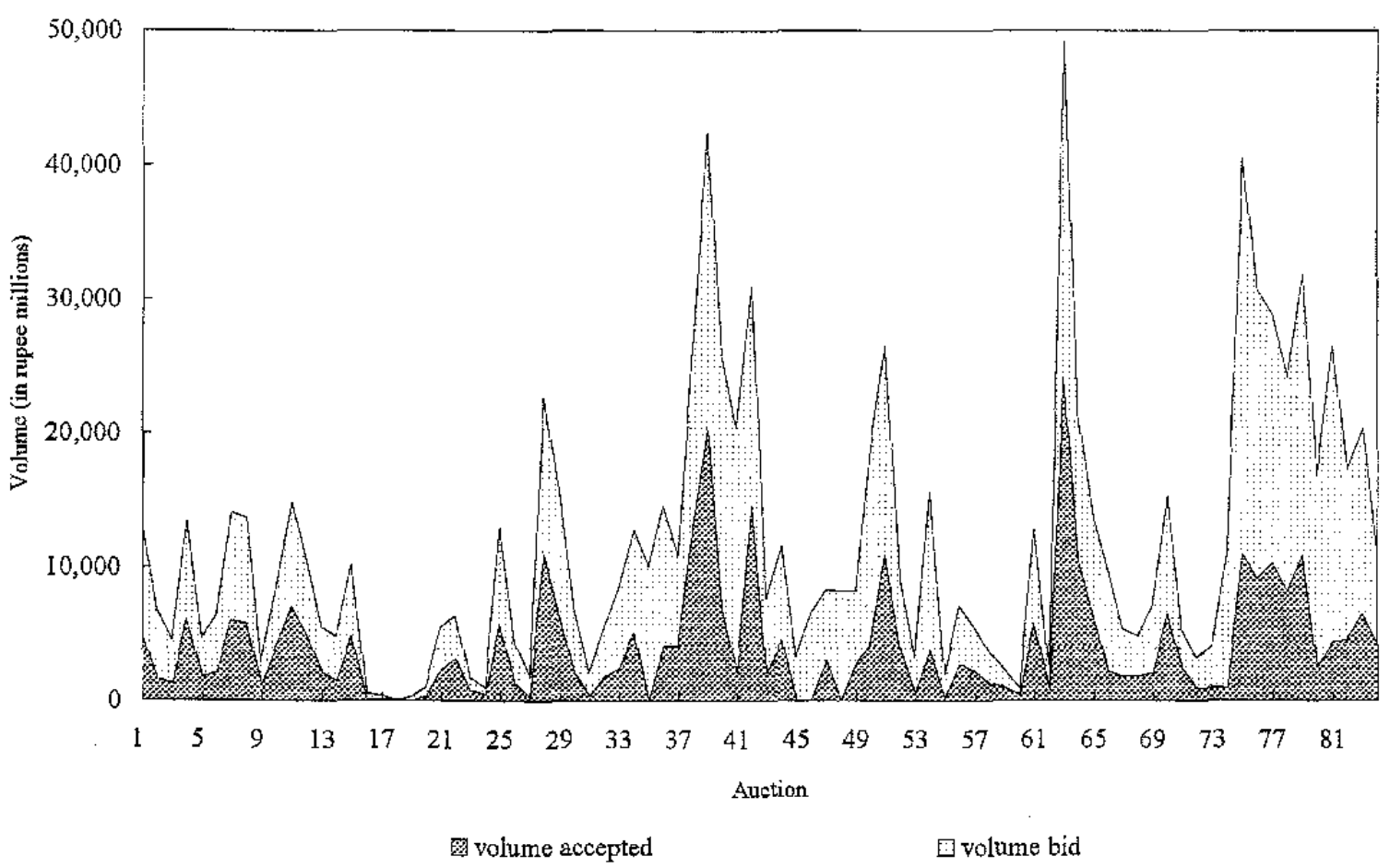




\section{Bidding Profitability}

\section{Definition of profitability}

The profitability of participating in an auction will be defined as the difference between the amount paid to obtain bills and their value in the secondary market shortly after the auction. An examination of profitability should provide important indicators of how the auction market functions. First, a finding that profitability is relatively low and comparable in magnitude to that observed in other government securities auctions, such as those in industrialized countries, would be one indicator that the auction mechanism is working well and is not in itself adding significantly to the government's funding costs. Second, differences in the profitability rates obtained by different bidders can provide evidence on the degree of competition in the auctions, and whether or not some bidder or groups of bidders have monopoly power and are bidding relatively aggressively. Third, hypotheses derived from auction theory might be testable by relating profitability to certain other features of the auctions and bidders.

The available data allowed the calculation of the realized profits and profit rate obtained by each successful bidder from auction twenty five onwards. Suppose that a certain bidder $b$ in some auction $a$ submits a schedule of $n$ price-quantity pairs $\left\{\left(p_{\text {bal }}, q_{\text {bal }}\right), \ldots,\left(p_{\text {ban }} q_{\text {ban }}\right)\right\}$, the realized cut-off price is $c_{\mathrm{a}}$, and on the day following the auction the bid price for treasury bills in the when-issued market is bid $_{\mathrm{a}}(1)$ (all prices are in absolute terms). Then the bidder's profits $P F_{1 \mathrm{ba}}$ merely from buying in the auction and selling immediately is

$$
P F_{1 b a}=b i d_{a}(1) \sum_{p_{b a t} \geq c_{a}} q_{b a i}-\sum_{p_{b a i} \geq c_{a}} p_{b a i} q_{b a t}
$$

This equation can usefully be re-written as

$$
P F_{i b a}=\left(b_{a}(1)-c_{a}\right) \sum_{p_{b a i} \geq c_{o}} q_{b a i}-\sum_{p_{b a i} \geq c_{a}}\left(p_{b a i}-\mathcal{c}_{a}\right) q_{b a i}
$$

which shows that the profit obtained in such a discriminatory price auction equals the profit in a comparable uniform-price auction (that is, the difference between the when-issued market price and the cut-off price, multiplied by the amount won), less the value of the 'upper tail' of bids that exceed the cut-off price. The profit rate will be defined as the ratio of profits to the total value won, or

$$
P F R_{1 b a}=\frac{\text { bid }_{a}(1) \sum_{p_{b a i} \geq c_{a}} q_{b a i}-\sum_{p_{b a t} \geq c_{a}} p_{b a i} q_{b a i}}{\sum_{p_{b a i} \geq c_{a}} p_{b a i} q_{b a i}} .
$$


It may be unreasonable to assume in the context of the early development of secondary trading in Pakistani government securities that a significant participant in the auction could sell all the bills he had won on a single day in the when-issued market without drastically depressing the price. As a more moderate alternative, profits and profit rates were calculated assuming that each bidder sold the bills won in equal tranches in the course of the five days follow the auction. On the first two of these days trading would have been conducted on a when-issued basis, so there is no cost of carry, but cost of carry needs to be deducted from profits on the following three days; the offer rate on interbank loans was used as a proxy for the cost of carry. Thus, if the daily interbank rate on day $t$ is denoted by $i(t)$, the alternative measure of profits $P F_{2 \mathrm{ba}}$ is defined as $P F_{1 \mathrm{ba}}$ in equation (1) above, but with bid $d_{\mathrm{a}}(1)$ replaced by

$$
\frac{1}{5}\left[b i d_{a}(1)+b i d_{a}(2)+\frac{b i d_{a}(3)}{(1+i(3))}+\frac{b i d_{a}(4)}{(1+i(3))(1+i(4))}+\frac{b i d_{a}(5)}{(1+i(3))(1+i(4))(1+i(5))}\right] \text {, }
$$

and similarly an alternative rate of profitability $P F R_{2 \text { ba }}$ can be defined.

\section{Mean profit rates}

Estimates were made of the profits obtained by bidders in the 60 auctions for which the necessary secondary market information was available. Total profits defined by $P F_{1 \mathrm{ba}}$ (that is, from buying and selling immediately in the when-issued market) amounted to Rs 302 million over these auctions (approximately US\$10 million at the then prevailing exchange rate) on a total value of Rs 267,538 million bills sold (with a face value of Rs 283,896 million). The corresponding overall weighted average profit rate $P F R_{1 \mathrm{ba}}$ was 11.27 basis points. The weighted mean profit rate obtained by selling during the five trading days following each auction $\left(P F R_{2 \mathrm{ba}}\right)$ was 13.29 basis points. Thus, mean profitability of participating in the Pakistani treasury bill auctions during this period was significantly positive, so in that sense bid shading occurred, but the level of profitability seems to have been quite low. ${ }^{16}$ Commercial banks do not seem to have made exceptionally large profits at the expense of government merely by participating in the auctions.

These profitability rates can be compared with an estimated rate of about 4 basis points estimated by Cammack (1979) in auctions for three-month U.S. treasury bills during the 1970s, and of about 1.5 basis points estimated by Spindt and Stolz (1993) for auctions during

\footnotetext{
${ }^{16}$ Another way to look at the issue of bid shading is to consider that, if the same face value of bills had been sold in a uniform price auction, the average price bid would have had to be 13.52 basis points higher for the same revenue to have been obtained. Bolton (1973) estimates that if uniform pricing were introduced into the U.S. Treasury bill auctions, revenue would be maintained if the quantity of bills demand increased by 1 percent.
} 
the 1980s, while Umlauf (1993) estimates profitability at about 1.6 basis points in discriminatory-price auctions for Mexican one-month bills; Simon (1994) finds that the profitability of participating in auctions for longer maturity U.S. government bonds and following a 'buy and sell' strategy can reach about 1 basis points. ${ }^{17}$ Thus, even after allowing for the longer maturity of the Pakistani bills, the observed profitability of auction participation in Pakistan was rather greater than the rates observed in the primary market for U.S. government securities. The latter market, however, is very deep and supported by an extremely liquid and sophisticated secondary market. These structural differences are illustrated by the fact that the range of bids in the U.S. primary market and bid-ask spreads in the U.S. secondary market are about an order of magnitude smaller than those typical of Pakistan during this period. Furthermore, the availability in the U.S. of when-issued trading before the auction may significantly reduce the risk of participation (Viswanathan and Wang (1999) present an interesting model of a treasury bill auction market with when-issued trading). Hence, the higher rate of profitability obtained by auction participants in Pakistan may largely reflect the greater risks they face.

The mean profit rates by auction are plotted in Figure 4 . It can be seen that the two measures of profitability move together closely (the correlation between the two measures of profitability by bank is 0.854 ), and both are quite variable (the unweighted standard deviation of $P F R_{\mathrm{lba}}$ is 29.64). On numerous occasions profits were negative. Profitability seems to have been somewhat higher during the earlier auctions $\left(P F R_{1 \mathrm{ba}}\right.$ averaged 24 basis points over auctions 25 through 44; for unknown reasons profitability was especially high in auction 28), and rather lower and more stable during the period of a constant cut-off price (auctions 45 through 62).

Table 1 shows the weighted mean profit rates for each bank over the largest available sample, along with indicators of whether a bank is foreign or domestic, privately or publicly owned, and summary statistics on bidding behavior. Also reported are the results of tests of the equality of each bank's profitability with the weighted average of all other banks. The tests include t-tests using conventional and heteroskedasticity-consistent standard errors (see White, 1980), and a Wilcoxon summed rank test, which should be more robust but applies to unweighted profit rates. Tests were also performed to compare profitability between various groups of bidders, namely foreign versus domestic banks, and privately owned versus public. Results for sub-samples, and for other groupings of bidders (such as very small or infrequent bidders, and very large or frequent bidders) are similar and are therefore not shown.

\footnotetext{
${ }^{17}$ Feldman and Reinhart (1995) find that in IMF gold sales during the 1970s, the mean winning price was 12 basis points below the secondary market price when discriminatory pricing was used.
} 
Figure 4. Mean Profit Rates

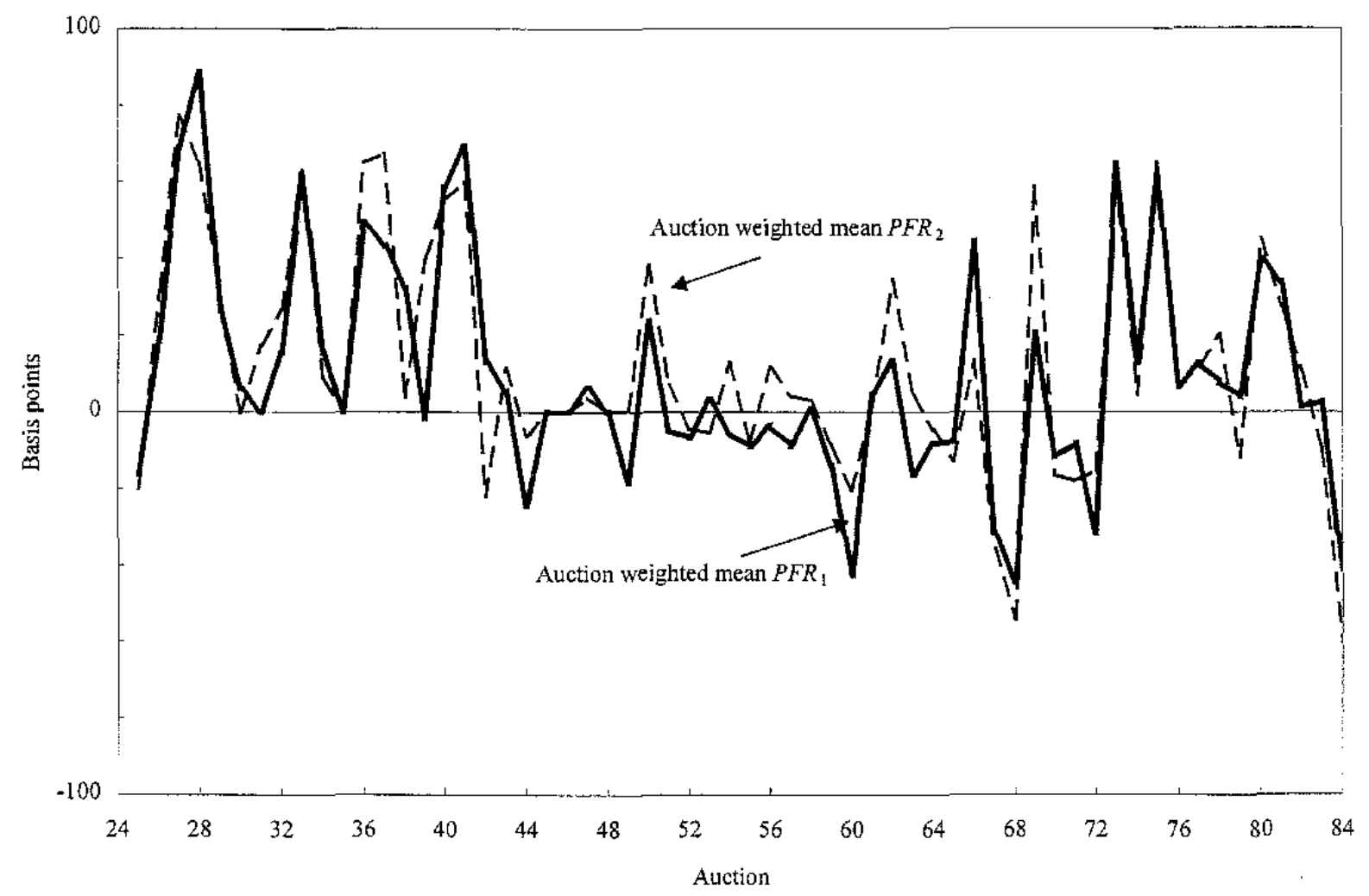

All the test results suggest that profitability did not differ systematically between most bidders, and only very few individual banks earned significantly more or less than the remainder. Data on profitability give no indication of collusion between any sub-set of bidders. However, two publicly-owned banks, including the bank that bid and won the greatest volume of bills, did achieve significantly lower rates of profitability, especially when profitability measure 2 is considered. The relatively poor performance of the largest bidder can be attributed to a number of factors: it may be that, as a publicly-owned institution, its management made less effort to maximize profits or felt itself under pressure to hold down the government's borrowing costs, and therefore bid less aggressively. However, another plausible explanation is that the bank was hampered by its very size, as could occur if it had to maintain an inventory of bills in order to meet retail demand or to fulfill its liquid asset requirement, and due to the thinness of the secondary market it had to obtain a large volume in the primary market even at a relatively high price. Possibly, if this large bank ever acquired surplus bills in the auctions, its attempts to dispose of them in the secondary market would depress the secondary market price and thus its profits. 
Table 1. Bidding Behavior and Profitability by Bank

\begin{tabular}{|c|c|c|c|c|c|c|c|c|c|c|c|c|c|c|c|}
\hline \multirow[b]{3}{*}{ Eank } & \multirow{2}{*}{\multicolumn{7}{|c|}{$\begin{array}{c}\text { Saraple: all observations } \\
\text { Bidding behavior }\end{array}$}} & \multicolumn{8}{|c|}{ Sample: suretions 25-84 } \\
\hline & & & & & & & & \multicolumn{4}{|c|}{ Profit rate 1} & \multicolumn{4}{|c|}{ Profit rate 2} \\
\hline & $\begin{array}{l}\text { foreign } \\
=1 \text { if bidder } \\
\text { foreign } \\
\text { owned }\end{array}$ & $\begin{array}{l}\text { private } \\
=1 \text { if bidde } \\
\text { privately } \\
\text { owned }\end{array}$ & & $\begin{array}{l}\text { Total face } \\
\text { ralue bid }\end{array}$ & $\begin{array}{l}\text { Total face } \\
\text { value won }\end{array}$ & $\begin{array}{l}\text { Frequency } \\
\text { of partici- } \\
\text { pation }\end{array}$ & $\begin{array}{l}\text { Frequency } \\
\text { of success- } \\
\text { full partici- } \\
\text { pation. }\end{array}$ & $\begin{array}{l}P F R_{1} \\
\text { Weighted } \\
\text { mean } \\
\text { profit rate }\end{array}$ & $\begin{array}{l}\text { trstatistic } \\
\text { based on } \\
\text { conven- } \\
\text { tiongl } \\
\text { standard } \\
\text { errors }\end{array}$ & $\begin{array}{l}\text { t-statistic } \\
\text { based on } \\
\text { 'White' } \\
\text { standard } \\
\text { errors }\end{array}$ & $\begin{array}{l}\text { Normal- } \\
\text { ized tank. } \\
\text { sijen tesi } \\
\text { statistic }\end{array}$ & $\begin{array}{l}P F R_{2} \\
P F R_{2} \\
\text { Weidthted } \\
\text { mean } \\
\text { profit rate }\end{array}$ & $\begin{array}{l}\text { t-statistic } \\
\text { bezed on } \\
\text { conven- } \\
\text { tional } \\
\text { stardard } \\
\text { errors }\end{array}$ & $\begin{array}{l}\text { t-statistic } \\
\text { based an } \\
\text { 'White' } \\
\text { standard } \\
\text { errors }\end{array}$ & $\begin{array}{l}\text { Nomal- } \\
\text { izod rank- } \\
\text { sign test } \\
\text { statisicic }\end{array}$ \\
\hline 122 & & 0 & 0 & 300 & 0 & 3 & 0 & $\ldots$ & $\ldots$ & $\ldots$ & $\ldots$ & $\ldots$ & $\ldots$ & $\ldots$ & $\ldots$ \\
\hline 127 & & 1 & 1 & 7,205 & 2,765 & 41 & 26 & 93.892 & 0.241 & 0.412 & 0.633 & 17.401 & 0.375 & 0.690 & 0.881 \\
\hline 422 & & 0 & 1 & 32,390 & 16,605 & so & 34 & 17.022 & 1.331 & 1.087 & 0.024 & 22.324 & $2.078 *$ & 1.284 & -0.365 \\
\hline 438 & & 1 & 1 & 23,605 & 11,780 & 50 & 38 & 5.632 & $\cdot 1.090$ & -0.677 & -0.514 & 9.821 & -0.668 & -0.383 & -0.252 \\
\hline 441 & & 0 & 1 & 135 & 50 & 6 & 2 & 36.630 & 0.312 & 1.388 & $1.833+$ & 9.309 & -0.049 & -0.119 & 0.464 \\
\hline 496 & & 1 & 1 & 42,618 & 15,603 & 49 & 26 & 17.178 & 1.322 & 0.684 & 1.066 & 19.833 & 1.453 & 0.899 & $0.9 \$ 1$ \\
\hline 514 & & 0 & 1 & 1,895 & 1,090 & 21 & 12 & 14.377 & 0.179 & 0.528 & 0.328 & 17.546 & 0.243 & 0.554 & 0.841 \\
\hline 523 & & 1 & 1 & 1,250 & 450 & 3 & 2 & 9.883 & $.0,051$ & -0.146 & 0.801 & 4.443 & -0.325 & -0.725 & 0.281 \\
\hline 524 & & 0 & 0 & 4,240 & 2,170 & 20 & 12 & 14.249 & 0.242 & 0.298 & 1.142 & 21.534 & $0.666 ́$ & 0.955 & $1.614+$ \\
\hline 555 & & 0 & 0 & 49,840 & 26,755 & 41 & 32 & 15.825 & 1.363 & 0.750 & -0.189 & 17.717 & 1.314 & 0.855 & -0.458 \\
\hline 563 & & 0 & 0 & $13,2 \leq 0$ & 10,550 & 13 & 10 & 14.423 & 0.575 & 0.274 & -0.432 & 25.984 & $2.304 *$ & I. 089 & 0.849 \\
\hline 574 & & D & 1 & 100 & so & 1 & 1 & 63.198 & 0.701 & $\ldots$ & 1.520 & 64.036 & 0.680 & $\ldots$ & 1.498 \\
\hline 581 & & 0 & 1 & 19,210 & 11,185 & 26 & 20 & 12.140 & 0.163 & 0.148 & $1.645+$ & 10.543 & -0.515 & -0.512 & 0.726 \\
\hline 586 & & 0 & 1 & 300 & 300 & 1 & 1 & -17.723 & -0.876 & $\ldots$ & -1.359 & -21.540 & -1.045 & ... & -1.398 \\
\hline 608 & & 1 & 1 & 2,246 & 1,515 & 34 & 26 & 1,004 & -0.698 & $-2.152 *$ & 0.190 & 13.125 & -0.012 & -0.029 & 0.851 \\
\hline 610 & & 1 & 1 & 5,875 & 2,300 & 37 & 19 & 14.354 & 0.258 & 0.431 & 1.406 & 12.529 & -0.064 & -0.100 & 0.850 \\
\hline 625 & & 1 & 1 & 67,805 & 42,390 & 44 & 33 & 5.264 & .2 .344 & -1.089 & -0.534 & 10.355 & -1.130 & -0.680 & -0.693 \\
\hline 642 & & 1 & 1 & 810 & 455 & 12 & 8 & -5.184 & -0.612 & $-3.949 * *$ & $-1.824 \div$ & -6.191 & -0.720 & $-2.609^{* *}$ & $-1.817+$ \\
\hline 648 & & 1 & 1 & 3,595 & 1,805 & 35 & 30 & 2.689 & -0.637 & $-1.876+$ & -0.832 & 4.670 & -0.537 & -1.587 & -0.752 \\
\hline 650 & & 0 & 1 & 365 & 205 & 12 & 10 & 4.703 & -0.164 & -0.650 & -0.985 & 6.484 & -0.169 & -0.619 & -0.810 \\
\hline 653 & & 1 & 1 & 660 & 295 & 22 & 11 & -3.521 & -0.443 & -1.162 & 0.593 & .0 .403 & .0 .407 & -0.884 & 0.325 \\
\hline 665 & & 1 & 1 & 3,005 & 2,113 & 23 & 17 & 0.487 & -0.867 & -1.542 & -0.945 & 4.651 & -0.691 & -1.186 & .0 .307 \\
\hline 666 & & 1 & 1 & 51,251 & 24,182 & $\$ 1$ & 35 & 23.543 & $3.500 \mathrm{m*}$ & 1.294 & 1.428 & 26.340 & $3.698 \mathrm{m*}$ & $1.300+$ & I.110 \\
\hline 668 & & 0 & 0 & 1,870 & 915 & 24 & 15 & 24.059 & 0.675 & 1.243 & 1.309 & 29.184 & 0.833 & 1.531 & I. .078 \\
\hline 685 & & 1 & 1 & 2,055 & 1,050 & 25 & 17 & 5.334 & -0.336 & -0.541 & $-2,021 *$ & 15.568 & 0.133 & 0.356 & -1.322 \\
\hline 692 & & 1 & 1 & 2,440 & 1,760 & 23 & 15 & 28.690 & 1.277 & 0.635 & -0.473 & 36,050 & $1.659+$ & 0.938 & 0.308 \\
\hline 695 & & 1 & 1 & 21,870 & 8,540 & 37 & 23 & 15.602 & 0.707 & 0.590 & $2.006 *$ & 14.275 & 0.158 & 0.137 & 0.748 \\
\hline 701 & & 0 & 0 & 87,155 & 50,700 & 40 & 33 & 4.899 & $.2 .771 * *$ & -1.258 & -0.458 & 0.468 & $-5.624=$ & $-2.304 *$ & .0 .380 \\
\hline 707 & & 1 & 1 & 7,200 & 2,675 & 32 & 18 & 10.479 & .0 .072 & -0.099 & 0.763 & 8.144 & -0.464 & $-0,550$ & 0.118 \\
\hline 715 & & 0 & 0 & 2,210 & 1,560 & 10 & 9 & 13.620 & 0.162 & 0.313 & 2.231 & 6.495 & .0 .466 & -1.460 & 0.060 \\
\hline 721 & & 1 & 1 & 19,565 & 11,815 & 49 & 33 & 11.862 & 0.114 & 0.090 & 0.578 & 17.183 & 0.746 & 0.621 & 0.653 \\
\hline 723 & & 0 & 0 & 12,141 & 5,635 & 38 & 23 & -10.111 & $-2.838 * *$ & $-5.587 * *$ & $-3.480 * \pi$ & -10.041 & $-3.080=*$ & $-3.628 * *$ & $-2.724 * *$ \\
\hline 729 & & 0 & 1 & 430 & 175 & 13 & 7 & 19.761 & 0.196 & 0.900 & 1.386 & 20.336 & 0.161 & 0.677 & 0.346 \\
\hline 759 & & 1 & 1 & 5,555 & $2,21.5$ & 17 & 14 & 19.439 & 0.672 & 1.382 & 1.301 & 19.761 & 0.528 & 1.212 & $1.674+$ \\
\hline 779 & & 0 & 1 & 1,137 & 232 & 17 & 11 & 11.348 & 0.002 & 0,008 & -1.449 & 16.060 & 0.073 & 0.254 & -1.290 \\
\hline 797 & & 0 & 1 & 207 & 167 & 8 & 8 & -1.933 & -0.297 & $-3.754 * *$ & $-1.882+$ & 5.128 & -0.183 & -1.261 & -0.911 \\
\hline 802 & & 0 & 0 & 5,471 & 3,151 & 18 & 10 & 51.649 & $4.008 * \pi$ & 1.098 & -0.784 & 66.130 & $5.247=*$ & $3.154^{* \times}$ & -0.001 \\
\hline 819 & & 1 & 1 & 17,160 & 5,935 & 39 & 22 & 11.396 & 0.017 & 0.022 & 1.222 & 8.560 & -0.639 & -0.812 & 0.374 \\
\hline 820 & & 1 & 1 & 9,355 & 5,205 & 41 & 25 & 3.203 & -1.024 & -1.205 & -1.409 & 5.860 & -0.938 & -1.030 & .1 .354 \\
\hline 834 & & 0 & 1 & 1,035 & 370 & 17 & 10 & 10.858 & -0.014 & -0.026 & -0.564 & 6.195 & -0.237 & -0.407 & $\cdot 1.374$ \\
\hline 854 & & 0 & 1 & 6,111 & 1,685 & 39 & 21 & 11.297 & 0.002 & 0.002 & 0.666 & 11.433 & -0.133 & -0.159 & 0.862 \\
\hline 855 & & 0 & 0 & 1,805 & 840 & 11 & 9 & 11.879 & 0.031 & 0.043 & 0.705 & 19.462 & 0.309 & 0.543 & 0.969 \\
\hline 875 & & 0 & 1 & 853 & 163 & 7 & 5 & 4.837 & -0.143 & $-1.762+$ & 0.106 & 2.896 & -0.230 & -1.492 & -0.615 \\
\hline 887 & & 1 & 1 & 170 & 95 & 4 & 2 & 1.624 & -0.164 & -0.979 & -0.448 & 6.007 & -0.123 & -0.412 & -0.266 \\
\hline 982 & & 1 & 1 & 130 & 80 & 9 & 6 & -0.714 & -0.187 & $-2.109 *$ & -0.939 & 7.466 & -0.090 & -1.285 & -0.234 \\
\hline 1052 & & 0 & 1 & 5,690 & 1,905 & 51 & 20 & 9.713 & -0.119 & -0.174 & -0.898 & 17.780 & 0.339 & 0.494 & -0.201 \\
\hline$: 427$ & & 0 & 1 & 2,100 & 825 & 14 & 8 & 13.786 & 0.126 & 0.100 & -0.886 & 16.527 & 0.160 & 0.127 & -0.861 \\
\hline 1429 & & 0 & 1 & 950 & 250 & 13 & 7 & 11.043 & -0.006 & -0.021 & 0.257 & 12.985 & -0.009 & -0.023 & -0.252 \\
\hline 1431 & & 0 & 1 & 750 & 450 & 3 & 2 & -38.355 & $-1.838+$ & -0.748 & -0.683 & -39.534 & $-1.948 \div$ & -0.853 & .0 .881 \\
\hline 1433 & & 0 & 1 & 235 & 0 & 9 & 0 & $\ldots$ & $\ldots$ & $\ldots$ & $\ldots$ & .. & $\ldots$ & ... & $\ldots$ \\
\hline 1435 & & 0 & 1 & 1,990 & 725 & 16 & 12 & 19.904 & 0.405 & 0.694 & 0,748 & 19.559 & 0.292 & 0.457 & 0.366 \\
\hline 1437 & & 0 & 1 & 625 & 150 & 3 & 2 & 2.295 & -0.192 & -4.234 «m & $.0,439$ & 4.500 & 0.187 & .0 .894 & -0.658 \\
\hline 1439 & & 0 & 1 & 35 & 5 & 3 & 1 & 2.891 & -0.033 & $\ldots$ & -0.301 & 2.103 & -0.043 & $\ldots$ & -0.502 \\
\hline \multicolumn{3}{|c|}{ All bidders } & & 550,250 & 283,896 & & & 11.274 & $\ldots$ & $\ldots$ & & 13.302 & $\ldots$ & $\ldots$ & \\
\hline \multicolumn{3}{|c|}{ Foreigr banks } & & 295,424 & 145,023 & & & 11.665 & 0.370 & 0.195 & 0.666 & 14.949 & 0.819 & 1.5 .54 & 0.692 \\
\hline \multicolumn{3}{|c|}{ Frivate bartks } & & 371,968 & 181,620 & & & 12.040 & $2.127^{*}$ & 0.948 & 0.825 & 15.157 & $2.286^{*}$ & 1.093 & 0.193 \\
\hline
\end{tabular}




\section{Profitability and auction theory}

Further insights can be obtained by relating realized profitability to features of the individual auctions and the bidders' behavior. Ultimately it would be desirable to test the implications of auction theory. However, despite the volume and sophistication of the existing literature on auctions, no comprehensive theoretical treatment is available of multiple-unit, multiplebid repeated auctions with a resale market, such as treasury bill auctions. In the case of the auctions for Pakistani treasury bills, the uncertainty over the amount to be sold presents a further complication. Hence, any hypotheses to be tested can have at best an heuristic basis in theory.

A model of a multiple-unit, multiple-bid auction that seems to fit the Pakistan case relatively closely is provided by Nautz and Wolfstetter (1997). Each bidder is assumed to be sufficiently small that it behaves as a price taker in the auction, and the aggregate quantity and cut-off price at auction is not affected by its bidding decision. ${ }^{18}$ For each point along the bid schedule, the bidder's marginal expected payoff depends on the difference between the bidder's true valuation and the amount paid, and the probability of the marginal bid being accepted. The bidder therefore faces a trade-off: the bid schedule can be shaded downwards more to increase the payoff rate, but the quantity of bills the bidder can expect to win is thereby reduced. This trade-off leads even a risk-neutral bidder to shade its bid and earn positive profits; risk aversion reduces but does not eliminate bid shading. Bid shading is zero at the lowest possible cut-off price and tends to be greater the higher the cut-off price, because a high price bid is very likely to be accepted anyway and the "cost' to bid shading is less.

In the interpretation of the model used here, the payoff from winning may depend both on the post-auction secondary market price and other, possibly bidder-specific factors (for example, meeting inventory needs or fulfilling a liquid asset requirement). If the secondary market demand for the bills shifts upwards, which is associated with an increase in the aggregate amount bid and the amount won, then at each possible cut-off price the trade-off between higher profits and the probability of a bid being accepted is unchanged. Hence, expected total profits are unaffected, but the rate of profitability decreases due to the increase in the volume sold. This reasoning also suggests that if a large volume of bills was sold in the

${ }^{18}$ This model assumes a single source of risk (expressed in the distribution function for the cut-off price), and a downward-sloping demand schedule for each bidder (which may, however, be identical across bidders). The latter assumption may be tolerable in the case of the Pakistani treasury bill auctions, because bid-offer spreads in the secondary market tended to be quite large (on the order of 50 basis points in terms of annualized yields); if a bidder won a quantity of bills such that he would not sell at the secondary market bid price nor buy at the offer price, then the total payoff would depend just on the bidder's individual demand for bills. 
previous auction, so that banks are holding a large stock of close substitute for the new bills to be auctioned, then profits should be lower.

An increase in the expected cut-off price would normally tend to increase the expected profitability rate, because, as explained, bid-shading and profitability increase with price. However, Nautz and Wolfstetter show that, if bid-shading (and thus profitability) decreases at every cut-off price due to a shift in the distribution of that variable, then the new distribution is stochastically dominated by the old, and so the expected cut-off price must have increased: intuitively, if the seller is more determined to achieve a high price, then the trade-off is less favorable and bidders have to shade less if they are to acquire sufficient bills. Hence, an increase in the expected cut-off price (which decreases in the expected volume won and the ratio of winning bids to total bids) could raise or lower the expected profitability rate.

An upward shift in the bidder-specific demand for bills, which leads a bidder to bid more for the same expected secondary market price, reduces its expected profits. A bidder that bought a large volume in a recent auction is likely to have relatively low demand for new bills, and should therefore make somewhat higher profits. An individual bank may also on occasion be eager to acquire at least a minimum quantity of bills, perhaps to meet inventory needs, and therefore present a relatively price-inelastic bid schedule. A large proportion of bids by such a bank is likely to be accepted, and profitability would be reduced. Banks may also differ on a sustained basis in how aggressively they bid and the average profits they make in the auctions, perhaps due to differences in risk aversion, the importance to them of retailing treasury bills, or managerial incentives; such persistent differences can be captured econometrically through the inclusion of fixed effects.

Considerations of risk are likely to be important determinants of bidding behavior and the return on participating in the auction. The most important sources of risk for each bidder are uncertainty over the aggregate demand for bills, uncertainty over the cut-off price that the government will choose to set, given aggregate demand, and covariance between returns on bills possibly acquired at the forthcoming auction and other assets in the bidder's portfolio. Although in this model risk aversion reduces the degree of bid shading, the greater the risk for given risk aversion, the higher the expected return. Assessments of risk are not directly observable, so for estimation purposes proxies must be used. Possible proxies include the dispersal of bids made by each bidder and of all bids in a particular auction, and the variability of secondary market prices for bills in the days leading up to the auction.

Some of the hypotheses presented above are consistent with other theories of auction behavior. In some regards a discriminatory price auction (with unit bids) is analogous to a first-price, common value auction for a single unit, which has been dealt with extensively in the theoretical literature, since in each case a winning bidder pays the price bid. Such a situation may give rise to the 'winner's curse,' which can be understood as arising because winning implies that all other bidders had a lower valuation of the object being sold, so on average the winner has an over-optimistic prior expectation of the object's value. To compensate for this risk, bids are shaded downwards, and generally expected profits are 
positive. Greater dispersion of opinion about the true value of the object being sold and the cut-off price, as indicated by the dispersion of bids for each bidder or across bidders, should lead to greater bid shading. The more bidders are present, the worse the winner's curse, but at the same time competition is more intense; an exogenous increase in the number of bidders may raise or lower profits, although eventually expected profits should go to zero. ${ }^{19}$ For a multi-unit auction, one might conjecture that the winner's curse is mitigated, the more is actually sold (in the extreme, if every bid is accepted, winning does not convey information as to the true value). Hence, compensation for the winner's curse should decrease with the share of bids that are met. Bikhchandani and Huang (1989) set out a model of a multi-unit auction with a resale market, albeit with bids restricted to unit quantities, and show that in general bidders will shade their bids. Spindt and Stolz (1992) argue based on this model that the expected cut-off price should increase with the number of bidders, and decrease with the quantity sold. However, as stressed for example by Bank and Zender (1993), it is unclear to what extent the results of this literature on unit-bid auctions carry over to the case with multiple bids; Wilson (1979) shows that in an auction for shares expected revenue for the seller and the expected profitability rate for the buyers can be independent of the number of bidders.

\section{Specification of regressions on profitability}

The theoretical literature suggest certain relationships between expected profitability and the actual or expected value of other variables. Expectations are not observed, but under the assumption of rational expectations realized the realization of a variable should equal its expectation plus a white noise error term. The realizations can be used in estimation, provided that the 'errors in variables' are dealt with through the employment of instrumental variables. In this case instrumental variables estimation is also advisable in order to remove statistical bias due to possible simultaneity between variables. ${ }^{20}$ These considerations lead to the following specification to be used in estimation:

$$
\begin{aligned}
P F R_{\mathrm{i}}= & \alpha_{1} S D P B I D+\alpha_{2} S D T B O F F+ \\
& \alpha_{3} A V+\alpha_{4}(A W / A V)+\alpha_{5} A W(-1)+\alpha_{6} V+\alpha_{7}(W / V)+\alpha_{8} W(-1)+ \\
& \Sigma \alpha_{\mathrm{fb}}(\text { fixed effects dummies })+\alpha_{\mathrm{a} 28} \text { (auction } 28 \text { dummy) }+ \text { (error terms), }
\end{aligned}
$$

${ }^{19}$ This hypothesis may not hold if auction participation is an endogenous decision.

${ }^{20}$ For example, bidders may raise the quantity bid when they expect high profitability, and greater dispersion in a bank's bids in itself may reduce profitability in a discriminatory price auction unless offset by ex ante bid shading. 
for profitability measures $i=1,2$ achieved by bidder $b$ in auction $a^{21}$ The risk terms $S D P B I D$ is the standard deviation of the $\log$ price bid by bidder $b$ in auction $a$, and $S D T B O F F$ is the standard deviation of the secondary market log offer price for treasury bills during the five market days preceding auction $a$. The levels of auction-wide and bidderspecific demand are captured by $A V$ and $V$, respectively the $\log$ volume bid in auction $a$ by all bidders together and by bidder $b$ alone. The ratio of winning to total bids for all bidders $(A W / A V)$ is meant to capture aggregate supply effects. ${ }^{22}$ The equivalent ratio for bidder $b$ $(W / V)$ could capture other bidder-specific effects. ${ }^{23}$ Also possibly relevant are $A W(-1)$, the log volume of winning bids in the previous auction, and $W(-1)$, the log volume won by $b$ in the most recent auction in which he participated. The fixed effects dummy for each bidder $b$ takes the value of 1 in observations relating to $b$ and zero otherwise. The dummy for auction 28 , which takes the value of 1 for observations from auction 28 and zero otherwise, is included to capture whatever exceptional circumstances led to very high profits on that one occasion. The instruments used include up to six lags of the predetermined variables, plus the dummies, and comprise both bidder-specific and auction-wide variables. ${ }^{24}$

The principal sample used in estimation consists of all observations for which profitability could be calculated, excluding observations that on a priori grounds may be expected not to be representative, namely, (i) those from the period when the cut-off price was nearly constant, when also the quantity bid and participation declined sharply and prices bid

${ }^{21}$ Subscripts are dropped where there is no chance of ambiguity.

22 The total volume bid and the volume accepted are highly correlated with one another, but the level of the volume bid and the ratio of winning to total bids (the win ratio) are not. Therefore, including these variables in this form on the right-hand side of the equation to be estimated is econometrically advantageous.

${ }^{23}$ For example, two bidders may submit the same total volume of bids, but one may submit a more concave bid schedule with fewer high- and low-priced bids; under some circumstances the more concave bid-schedule could result in a higher proportion of bids accepted, or lower unit costs.

${ }^{24}$ The bidder-specific instruments included lags one and two of WMP, SDPBID, $V$, and $W$, and the dummy variables for all the banks that were awarded bills during these auctions. The auction-wide instruments include the first lag of $C O, A W M P, A S D P B I D, A V, A W$, and $A W / A V$, and in addition lags two and six of $A W M P$ and $A V$. The employment of longer lags of only two of the aggregate variables was motivated by the need for parsimony given the relatively small number of auctions in the sample, and inspired by the results of Phillips and Hansen (1989), who suggest that the inclusion of numerous highly correlated instruments (especially when they are cointegrated) brings little gain in efficiency. Additional instruments included the dummy variable for auction 28 , and known pre-determined variables $S D T B O F F$ and $\operatorname{TBOFF}(-1)$. 
converged to the cut-off; and (ii) single bids, that is, individual bids submitted mostly by very small and infrequent participants. After taking lags to construct instrumental variables, 509 observations are available in this restricted sample. Regressions were also run using other samples so as to judge the stability of the estimates.

\section{Results of regressions on profitability}

The results of regressing profitability on the various explanatory variables are presented in Table 2. Included besides the estimated coefficients and standard errors and some familiar statistics are the estimated generalized $R^{2}$ statistic, which Peseran and Smith (1994) argues is a good measure of fit for an instrumental variables regression, and the term E'PZ'E, which is the instrumental variables equivalent of the sum of squared residuals. ${ }^{25}$

The regression results corroborate the hypotheses presented above. Looking at the principal specification for profitability measure 1 (column 1), the risk terms both enter with positive and highly significant coefficients; it seems that bidders require compensation for both the risk manifest in the dispersion of their bids, and that represented by fluctuations in the secondary market price of treasury bills. An increase in the total volume bid, that is, strong aggregate demand for bills, is associated with higher profits, and profits tend to be lower, the greater the proportion of this demand that is met (the supply effect). When a large volume of similar bills are outstanding, because a large volume was awarded in the previous auction, the reward to acquiring new bills is less. Turning to the bidder-specific quantity terms, a bidder who submits a relatively large volume of bids tends to achieve low profitability, but the proportion of bids accepted has only a weak positive effect on profitability (this term is therefore dropped from subsequent specifications). The lagged volume won has a positive effect on profits, suggesting that a bidder holding a relatively large inventory of similar bills will bid more aggressively and earn higher profits on the bills that are in fact won. Results for profitability measure 2 (shown in column 5) are similar.

The fixed effects are jointly significant. ${ }^{26}{ }^{27}$ Nonetheless, when they are excluded from the specification (see column 3 of Table 2), most other estimated coefficients are not greatly

\footnotetext{
${ }^{25}$ Heteroskedasticity-consistent estimators of the standard errors (White, 1980) were calculated, but the significance of estimated parameters was not greatly affected when they were employed.
}

${ }^{26}$ The relevant test statistic is 9.756 , which has an $\mathrm{F}(43,457)$ distribution and is highly significantly different from zero.

27 The regressions were run with the fixed effects replaced with dummy variables identifying groups of bidders, such as public sector banks, foreign banks, or small bidders. Almost all the estimated coefficients on these dummies were insignificantly different from zero. 
Table 2. Determinants of Profit Rates

\begin{tabular}{|c|c|c|c|c|c|c|c|}
\hline Dependent variable & $P R F_{1}$ & $P R F_{1}$ & $P R F_{1}$ & $P R F_{1}$ & $P R F_{2}$ & $P R F_{1}$ & $P R F_{1}$ \\
\hline \multirow[t]{2}{*}{ Estimation method } & IV & IV & IV & OLS & IV & IV & IV \\
\hline & $\begin{array}{l}\text { Fixed } \\
\text { effects }\end{array}$ & $\begin{array}{l}\text { Fixed } \\
\text { effects }\end{array}$ & $\begin{array}{l}\text { No fixed } \\
\text { effects }\end{array}$ & $\begin{array}{l}\text { Fixed } \\
\text { effects }\end{array}$ & $\begin{array}{l}\text { Fixed } \\
\text { effects }\end{array}$ & $\begin{array}{c}\text { Fixed } \\
\text { effects } \\
\text { Full } \\
\text { sample }\end{array}$ & $\begin{array}{c}\text { Fixed } \\
\text { effects } \\
\text { Auctions } \\
63-84\end{array}$ \\
\hline$S D P B I D$ & $\begin{array}{c}58.488 \\
(20.040)^{* *}\end{array}$ & $\begin{array}{c}46.439 \\
(17.122) * *\end{array}$ & $\begin{array}{c}24.187 \\
(10.850) *\end{array}$ & $\begin{array}{r}1.321 \\
(6.614)\end{array}$ & $\begin{array}{c}38.924 \\
(18.191)^{*}\end{array}$ & $\begin{array}{c}48.604 \\
(16.478)^{* *}\end{array}$ & $\begin{array}{l}103.954 \\
(15.145) * *\end{array}$ \\
\hline SDTBOFF & $\begin{array}{l}51.995 \\
(6.412)^{* *}\end{array}$ & $\begin{array}{l}54.527 \\
(5.950) * *\end{array}$ & $\begin{array}{l}54.223 \\
(4.864) * *\end{array}$ & $\begin{array}{l}51.604 \\
(4.793)^{* *}\end{array}$ & $\begin{array}{l}83.283 \\
(6.321)^{* *}\end{array}$ & $\begin{array}{l}54.239 \\
(5.212)\end{array}$ ** & $\begin{array}{r}17.637 \\
(18.120)\end{array}$ \\
\hline$A V$ & $\begin{array}{l}21.168 \\
(4.090)^{* *}\end{array}$ & $\begin{array}{l}20.890 \\
(4.002)^{* *}\end{array}$ & $\begin{array}{l}13.429 \\
(1.934)^{* *}\end{array}$ & $\begin{array}{l}13.127 \\
(1.770)^{* *}\end{array}$ & $\begin{array}{l}19.272 \\
(4.252)^{* *}\end{array}$ & $\begin{array}{l}18.294 \\
(3.350)^{* *}\end{array}$ & $\begin{array}{l}11.973 \\
(6.409)+\end{array}$ \\
\hline$A W / A V$ & $\begin{array}{l}-64.097 \\
(23.141) * *\end{array}$ & $\begin{array}{l}-37.583 \\
(8.135)^{* *}\end{array}$ & $\begin{array}{l}-34.909 \\
(6.031) * *\end{array}$ & $\begin{array}{l}-52.591 \\
(4.060)\end{array} * *$ & $\begin{array}{l}-19.782 \\
(8.643) *\end{array}$ & $\begin{array}{l}-23.136 \\
(6.790) * *\end{array}$ & $\begin{array}{l}-35.864 \\
(9.298) * *\end{array}$ \\
\hline$A W(-1)$ & $\begin{array}{l}-2.572 \\
(0.768)^{* *}\end{array}$ & $\begin{array}{l}-2.942 \\
(0.692) * *\end{array}$ & $\begin{array}{l}-2.924 \\
(0.581)^{* *}\end{array}$ & $\begin{array}{l}-2.498 \\
(0.571)^{* *}\end{array}$ & $\begin{array}{l}-4.262 \\
(0.735) * *\end{array}$ & $\begin{array}{l}-1.634 \\
(0.423)^{* *}\end{array}$ & $\begin{array}{l}-3.105 \\
(1.769)+\end{array}$ \\
\hline$V$ & $\begin{array}{l}-20.219 \\
(6.927) * *\end{array}$ & $\begin{array}{l}-22.471 \\
(6.546)\end{array} * *$ & $\begin{array}{l}-2.722 \\
(1.458)+\end{array}$ & $\begin{array}{c}-2.969 \\
(1.615)+\end{array}$ & $\begin{array}{l}-20.387 \\
(6.954) * *\end{array}$ & $\begin{array}{l}-11.183 \\
(4.605) *\end{array}$ & $\begin{array}{c}-8.361 \\
(10.706)+\end{array}$ \\
\hline$W / V$ & $\begin{array}{r}31.721 \\
(25.843)\end{array}$ & $\begin{array}{l}\ldots \\
\cdots\end{array}$ & $\begin{array}{l}\cdots \\
\cdots\end{array}$ & $\begin{array}{l}\ldots \\
\ldots\end{array}$ & $\begin{array}{l}\ldots \\
\ldots\end{array}$ & $\begin{array}{l}\ldots \\
\cdots\end{array}$ & $\begin{array}{l}\cdots \\
\cdots\end{array}$ \\
\hline$W(-1)$ & $\begin{array}{c}5.419 \\
(1.502)^{* *}\end{array}$ & $\begin{array}{c}5.825 \\
(1.436) * *\end{array}$ & $\begin{array}{c}3.656 \\
(1.143)^{* *}\end{array}$ & $\begin{array}{c}2.992 \\
(1.036) * *\end{array}$ & $\begin{array}{c}7.297 \\
(1.526)^{* *}\end{array}$ & $\begin{array}{c}4.744 \\
(1.219) * *\end{array}$ & $\begin{array}{c}5.214 \\
(1.776) * *\end{array}$ \\
\hline$A U C 28$ & $\begin{array}{c}69.219 \\
(12.055)^{* *}\end{array}$ & $\begin{array}{c}72.294 \\
(11.557)^{* *}\end{array}$ & $\begin{array}{l}68.321 \\
(8.965) * *\end{array}$ & $\begin{array}{l}54.572 \\
7.186 * *\end{array}$ & $\begin{array}{c}37.923 \\
(12.278) * *\end{array}$ & $\begin{array}{l}80.611 \\
(9.565)^{* *}\end{array}$ & $\ldots$ \\
\hline $\begin{array}{l}\text { Number of } \\
\text { observations }\end{array}$ & 509 & 509 & 509 & 535 & 509 & 726 & 305 \\
\hline $\begin{array}{l}\text { Mean of } \\
\text { dependent variable }\end{array}$ & 13.845 & 13.845 & 13.845 & 13.845 & 13.751 & 10.029 & 6.723 \\
\hline $\begin{array}{l}\text { Std. deviation of } \\
\text { dependent variable }\end{array}$ & 29.457 & 29.457 & 29.457 & 29.457 & 32.101 & 28.532 & 27.945 \\
\hline $\mathrm{R}^{2}$ & 0.370 & 0.384 & 0.464 & 0.562 & 0.400 & 0.350 & 0.475 \\
\hline Generalized $\mathrm{R}^{2}$ & 0.436 & 0.434 & 0.367 & $\ldots$ & 0.444 & 0.436 & 0.582 \\
\hline$E^{\prime} P Z^{*} E$ & 35101 & 32484 & 62303 & $\ldots$ & 31079 & 35440 & 28116 \\
\hline
\end{tabular}


affected; the most important change is that the coefficient on the individual volume term becomes much smaller absolutely and less significant, and the estimated coefficients on the other bidder-specific explanatory are also lowered. Estimating the model by OLS generally reduces the magnitude and significance of the estimated coefficients, especially those on bidder-specific variables and those that are not predetermined, such as the dispersal and volume of bids. Results are robust to changes in the sample: regression on the sample including singleton bids and the period of a fixed cut-off price (column 6) yielded similar coefficients except for those on the past volume won and on individual volumes bid, which are rather lower, as might be expected. Likewise, the results of regression on a sample including only the last 22 auctions (column 7), that is, after the period of a nearly fixed cutoff price, were not very different from those from the main sample, but with somewhat smaller estimated coefficients on some of the quantity variables and especially the individual volume bid; perhaps idiosyncratic variations in demand for bills became less important as the secondary market matured.

\section{PRices BID}

The explanations presented and tested above for the measured profitability of participating in the auctions, which are formulated primarily in terms of quantities, suggest that profitability will depend on aggregate demand and supply conditions, and on idiosyncratic factors. These factors have also implications for the level of the prices bid, so that for example strong demand or anticipated limited supply for bills will tend to raise both profitability and prices bid. The interpretation of the results of the profitability regressions can be checked by examining the relationship between prices bid and the same explanatory variables.

This approach, however, needs to be complemented by a more general examination of the determinants of bidding behavior. In particular, one may ask whether bidders determine their bid schedules in order to maximize profitability of buying in the auction and immediately thereafter 'marking to market' their positions, or whether they have other objectives, such as maximizing returns over the longer term; the question is whether bidders are following a 'buy and sell' or a 'buy and hold' strategy. Under the 'buy and sell' strategy, prices bid should be determined by the expected secondary market price following the auction, the expected cut-off, and measures of risk (insofar as they are not already incorporated in prices). Under the 'buy and hold' strategy, prices bid should be determined by the expected cut-off price, the price of substitute assets in the bidders' investment portfolio, and risk measures. A third possibility is that bidder-specific factors determine the prices bid. The approach taken here to assessing the relative importance of the three explanations is to estimate the relationship of prices bid to, respectively, the expected secondary market price, the price of outstanding treasury bills issued in the most recent auction (which are the closest substitute for the bills to be issued), and bidder-specific variables such as the individual quantity bid, in addition to risk measures and the expected cut-off price. Note that, in the absence of rationing, price terms should capture the information relevant for the determination of bidding behavior, and so one would expect that aggregate quantity variables would not be significant explanatory variables. 
Bidders cannot know the cut-off price and the subsequent secondary market value of bills when they determine their bid schedules, but must base their bids on expectations, which are unobserved. For estimation purposes, the realized values of these variables can be used, provided that an instrumental variables technique is employed in estimation The need for instrumental variables estimation is also motivated by the possible simultaneity between prices bid and certain candidate explanatory variables, such as the spread of bids.

With these motivations, the principal specification for the pricing of bids was chosen to take the form

$$
\begin{aligned}
W M P= & \beta_{1} A S D P B I D+\beta_{2} S D T B O F F+ \\
& \beta_{3} T B B I D(+1)+\beta_{4} C O+\beta_{5} T B O F F(-1)+ \\
& \beta_{6} V+\beta_{7}(W / V)+\beta_{8} W(-1)+ \\
& \Sigma \beta_{\mathrm{fb}}(\text { fixed effects dummies })+\beta_{\mathrm{a} 28}(\text { auction } 28 \text { dummy })+\text { (error terms), }
\end{aligned}
$$

where $W M P$ is the weighted mean of the log annualized prices bid by bidder $b$ in auction $a$. The risk terms are and $S D T B O F F$, as before, and $A S D P B I D$, which is the weighted standard deviation of all prices bid in auction $a{ }^{28}$ The term $T B B I D(+1)$ denotes the treasury bill bid price (how much one can sell a bill for) in the when-issued market on the day following auction $a, C O$ is the cut-off price in the auction, and $T B O F F(-1)$ is the treasury bill offer price (how much one must pay to acquire a bill issued in the previous auction) immediately before bids must be submitted. The bidder-specific terms (volume bid, winning ratio, past winning volume, and fixed effects) are the same as in the profitability regressions. Regressions were also performed including the other explanatory variables from the profitability regressions. The main sample is again that excluding singleton bids and the period of a stable cut-off price, but there are more observations ( 740 after construction of the instruments) because also the average prices bids from unsuccessful bidders are included. The instruments used are the same as in the profitability regressions.

Results are presented in Table 3. The first column shows the estimated coefficients from a regression of average prices bid just on the variables used to explain variations in profitability. The most prominent, but perhaps unsurprising result is that bidders who can be expected to be awarded a high share of their bids relative to the average also bid relative high prices. When a high aggregate volume is bid or when a low volume was sold in the previous auction then average prices bid are higher, presumably because bidders anticipate a higher

\footnotetext{
${ }^{28}$ Regressions were also run using the standard deviation of each bidder's prices bid, as in the profitability regressions; results were similar but significance levels tended to be somewhat lower (see below).
} 
Table 3. Determinants of the Average Price Bid

\begin{tabular}{|c|c|c|c|c|c|c|c|c|}
\hline Dependent variable & $W M P$ & $W M P$ & $W M P$ & WMP & $W M P$ & $W M P$ & $W M P$ & $W M P$ \\
\hline \multirow[t]{2}{*}{ Estimation method } & IV & IV & IV & IV & IV & OLS & IV & IV \\
\hline & $\begin{array}{l}\text { Fixed } \\
\text { effects }\end{array}$ & $\begin{array}{l}\text { Fixed } \\
\text { effects }\end{array}$ & $\begin{array}{l}\text { Fixed } \\
\text { effects }\end{array}$ & $\begin{array}{l}\text { No fixed } \\
\text { effects }\end{array}$ & $\begin{array}{l}\text { No fixed } \\
\text { effects }\end{array}$ & $\begin{array}{l}\text { Fixed } \\
\text { effects }\end{array}$ & $\begin{array}{c}\text { Fixed } \\
\text { effects } \\
\text { Full } \\
\text { sample }\end{array}$ & $\begin{array}{c}\text { Fixed } \\
\text { effects } \\
\text { Auctions } \\
63-84\end{array}$ \\
\hline$T B B I D(+1)$ & $\ldots$ & $\begin{array}{c}0.248 \\
(0.105)^{*}\end{array}$ & $\begin{array}{c}0.258 \\
(0.073) * *\end{array}$ & $\begin{array}{c}0.173 \\
(0.514)^{* *}\end{array}$ & $\begin{array}{c}0.118 \\
(0.059)^{*}\end{array}$ & $\begin{array}{r}-0.015 \\
(0.022)\end{array}$ & $\begin{array}{c}0.204 \\
(0.074)^{* *}\end{array}$ & $\begin{array}{r}0.073 \\
(0.085)\end{array}$ \\
\hline $\mathrm{CO}$ & $\ldots$ & $\begin{array}{c}0.312 \\
(0.175)^{+}\end{array}$ & $\begin{array}{l}0.200 \\
0.095^{*}\end{array}$ & $\begin{array}{c}0.192 \\
(0.070)^{* *}\end{array}$ & $\begin{array}{c}0.160 \\
(0.081)^{*}\end{array}$ & $\begin{array}{c}0.382 \\
(0.038)^{* *}\end{array}$ & $\begin{array}{r}0.106 \\
(0.084)\end{array}$ & $\begin{array}{c}0.335 \\
(0.147)^{*}\end{array}$ \\
\hline TBOFF(-1) & $\ldots$ & $\begin{array}{c}0.201 \\
(0.079)^{*}\end{array}$ & $\begin{array}{c}0.225 \\
(0.058)^{* *}\end{array}$ & $\begin{array}{c}0.243 \\
(0.035)^{* *}\end{array}$ & $\begin{array}{c}0.308 \\
(0.040)^{* *}\end{array}$ & $\begin{array}{c}0.254 \\
(0.026)^{* *}\end{array}$ & $\begin{array}{c}0.285 \\
(0.050)^{* *}\end{array}$ & $\begin{array}{c}0.283 \\
(0.066)^{* *}\end{array}$ \\
\hline SDTBOFF & $\begin{array}{c}0.414 \\
(0.171)^{*}\end{array}$ & $\begin{array}{r}-0.168 \\
(0.001)\end{array}$ & $\begin{array}{r}-0.127 \\
(0.095)\end{array}$ & $\begin{array}{r}-0.028 \\
(0.070)\end{array}$ & $\begin{array}{r}0.034 \\
(0.081)\end{array}$ & $\begin{array}{c}0.131 \\
(0.054)\end{array}$ & $\begin{array}{r}-0.141 \\
(0.098)\end{array}$ & $\begin{array}{r}0.137 \\
(0.210)\end{array}$ \\
\hline$A S D P B I D$ & $\ldots$ & $\begin{array}{r}-0.704 \\
(0.480)\end{array}$ & $\begin{array}{l}-1.149 \\
(0.178)^{* *}\end{array}$ & $\begin{array}{c}-0.821 \\
(0.127)^{* *}\end{array}$ & $\begin{array}{l}-0.763 \\
(0.147)^{* *}\end{array}$ & $\begin{array}{l}-0.451 \\
(0.073)^{* *}\end{array}$ & $\begin{array}{l}-1.188 \\
(0.184)^{* *}\end{array}$ & $\begin{array}{l}-1.284 \\
(0.216)^{* *}\end{array}$ \\
\hline$S D P B I D$ & $\begin{array}{r}-0.679 \\
(0.544)\end{array}$ & $\begin{array}{r}-0.622 \\
(0.587)\end{array}$ & $\ldots$ & $\ldots$ & $\ldots$ & $\ldots$ & $\ldots$ & $\ldots$ \\
\hline$A V$ & $\begin{array}{c}0.258 \\
(0.113)^{*}\end{array}$ & $\begin{array}{r}0.005 \\
(0.071)\end{array}$ & $\ldots$ & $\ldots$ & $\ldots$ & $\ldots$ & $\ldots$ & $\ldots$ \\
\hline$A W / A V$ & $\begin{array}{l}-4.120 \\
(0.913)^{* *}\end{array}$ & $\begin{array}{c}-1.113 \\
(0.484)^{*}\end{array}$ & $\cdots$ & $\cdots$ & $\ldots$ & $\cdots$ & $\cdots$ & $\ldots$ \\
\hline$A W(-1)$ & $\begin{array}{c}-0.046 \\
(0.020)^{*}\end{array}$ & $\begin{array}{r}0.010 \\
(0.011)\end{array}$ & $\ldots$ & $\ldots$ & $\ldots$ & $\ldots$ & $\cdots$ & $\ldots$ \\
\hline$V$ & $\begin{array}{r}0.203 \\
(0.158)\end{array}$ & $\begin{array}{r}-0.115 \\
(0.072)\end{array}$ & $\begin{array}{c}-0.133 \\
(0.064)^{*}\end{array}$ & $\begin{array}{c}-0.026 \\
(0.011)^{*}\end{array}$ & ... & $\begin{array}{r}0.022 \\
(0.015)\end{array}$ & $\begin{array}{r}-0.051 \\
(0.042)\end{array}$ & $\begin{array}{l}-0.215 \\
(0.064)^{* *}\end{array}$ \\
\hline$W / V$ & $\begin{array}{c}3.593 \\
(0.779)^{* *}\end{array}$ & $\begin{array}{c}1.311 \\
(0.373)^{* * *}\end{array}$ & & & & & & \\
\hline$(W / V)-(A W / A V)$ & $\ldots$ & $\ldots$ & $\begin{array}{c}1.517 \\
(0.367)^{* *}\end{array}$ & $\begin{array}{c}1.104 \\
(0.096)^{* *}\end{array}$ & $\ldots$ & $\begin{array}{c}0.759 \\
(0.040)^{* *}\end{array}$ & $\begin{array}{c}1.476 \\
(0.341)^{* *}\end{array}$ & $\begin{array}{c}1.735 \\
(0.351)^{* *}\end{array}$ \\
\hline$W(-1)$ & $\begin{array}{r}-0.007 \\
(0.009)\end{array}$ & $\begin{array}{r}-0.001 \\
(0.004)\end{array}$ & $\ldots$ & ... & $\cdots$ & $\cdots$ & $\ldots$ & $\ldots$ \\
\hline$A U C 28$ & $\begin{array}{c}1.049 \\
(0.347)^{* *}\end{array}$ & $\begin{array}{c}0.507 \\
(0.187)^{* *}\end{array}$ & $\begin{array}{c}0.588 \\
(0.186)^{* *}\end{array}$ & $\begin{array}{c}0.538 \\
(0.145)^{* *}\end{array}$ & $\begin{array}{r}0.536 \\
(0.170)\end{array}$ & $\begin{array}{c}0.704 \\
(0.106)^{* *}\end{array}$ & $\begin{array}{c}0.446 \\
(0.167)^{* *}\end{array}$ & ... \\
\hline Number of obs. & 740 & 740 & 740 & 740 & 740 & 764 & 1158 & 443 \\
\hline Mean of dep. var. & 0.021 & 0.021 & 0.021 & 0.021 & 0.021 & 0.021 & -0.050 & 0.004 \\
\hline $\begin{array}{l}\text { Std. dev. of dep. } \\
\text { var. }\end{array}$ & 0.476 & 0.476 & 0.476 & 0.476 & 0.476 & 0.476 & 0.510 & 0.488 \\
\hline $\mathrm{R}^{2}$ & 0.323 & 0.591 & 0.545 & 0.580 & 0.364 & 0.649 & 0.534 & 0.633 \\
\hline Generalized $\mathrm{R}^{2}$ & 0.347 & 0.457 & 0.455 & 0.407 & 0.321 & ... & 0.372 & 0.539 \\
\hline $\mathrm{E}^{\prime} \mathrm{PZ} \mathrm{E}^{\mathrm{E}}$ & 19.128 & 0.735 & 1.021 & 9.126 & 23.474 & $\ldots$ & 5.999 & 1.946 \\
\hline
\end{tabular}


price in the subsequent secondary market. An individual bidder that bids for a large volume, or that won relatively little the last time it participated in an auction, also tends to bid higher, although these effects are not statistically significant. A high spread of bids, indicating more uncertainty about the auction outcome, is associated with lower prices, but the coefficient on the standard deviation of past secondary market prices enters with the wrong sign.

The inclusion of price terms improves the explanatory power of the regression considerably (column 2), and eliminates the statistical significance of most quantity terms; the (expected) prices convey more information than the quantities. Of the quantity terms, only the win ratios and the individual volume bid were found to be significant; the standard deviation of prices bid by all bidders was found to be more significant than the equivalent measures for individual bidders.

The results of estimating a relatively parsimonious specification are shown in column 3 . Columns 4 and 5 show results obtained when the fixed effects are excluded, and when all bidder-specific terms are excluded. Several features stand out:

- The estimated coefficients on all three price terms are significantly greater than zero and of similar magnitude. It would appear that bidding behavior reflects a mixture of the "buy and sell' and 'buy and hold' strategies.

- The coefficients on the risk measures enter with the anticipated negative sign and are significantly different from zero. Greater uncertainty over the auction outcome and the subsequent value of the bills seems to lower the prices bid.

- Bidder-specific factors are of significance, but explain only about 13 percent of the variation in prices bid. The fixed effects are jointly significant. ${ }^{29}$ The coefficient on the relative share of bids accepted, which can be thought of as capturing a range of idiosyncratic factors, is of considerably magnitude and highly significantly positive. The volume bid by an individual enters with a negative sign; bidding a higher quantity, and keeping the expected win ratio unchanged involves submitting relatively many lowpriced bids. ${ }^{30}$

Estimating the model by OLS (column 6) has a marked effect on a number of parameter estimates. In particular, the coefficient on the future secondary market price becomes

29 The test statistic of 115.528 for the hypothesis that coefficients on all the fixed effects are zero, with an $\mathrm{F}(47,684)$ distribution, is highly significant. When, alternately, dummy variables identifying groups of bidders were included, the estimated coefficients were insignificant.

${ }^{30}$ The individual volume bid enters the estimated profitability equation with a positive sign, but the relevant sample contains only the accepted bids, which are ipso facto relatively high. 
insignificant, the coefficients on the standard deviation of secondary market prices and the volume bid reverse sign, and the coefficients on the bid spread and the relative win ratio become much smaller in magnitude. The adoption of an instrumental variables technique to relate prices bid to expectations thus seems warranted. When the same specification is estimated across the full sample for which all data are available (column 7), results are similar to those obtained from the more limited sample, except that the estimated coefficient on the volume bid is smaller in magnitude and no longer significant, presumably because of the inclusion of bids from very small bidders who may bid in a less sophisticated manner. Estimation across a sample including only observations from the last 22 auctions are again similar; the estimated coefficient on expected secondary market prices is smaller and less significant, perhaps because the instruments are not as effective in capturing expectations with so small a number of auctions.

\section{Conclusions}

The examination of bidding behavior during the first three years of Pakistani government treasury bills presented in this paper yields a number of findings:

- The typical pattern of bidding behavior was established relatively quickly, after about five or six auctions. The secondary market became active over the first year of the auctions.

- The average profitability of participating in the auctions was positive (as one would expect from auction theory), but quite low in absolute terms and when compared with the normal bid-ask spread in the secondary market. Profitability was on average higher than found in similar discriminatory-price auctions for government bills in other countries, but not unreasonably so given, in the case of Pakistan, the uncertainty over the quantity to be sold, the relative thinness of the secondary market, and the absence of when-issued trading before the auctions. Average profitability did not differ systematically across types of bidders, which, together with the large number of participants, suggests that collusion was not pervasive. In sum, as measure by profitability of bidding, the auctions do not seem to have been an expensive way to raise government financing.

- Again in conformity with the predictions of auction theory, expected profitability was higher, and the average price bid was lower, the greater the risks faced by bidders. These risks, which find expression primarily in the dispersion of bids, include in particular uncertainty surrounding the cut-off price that the government will select, and fluctuations in the level of demand for the new issue of bills.

- Profitability tended to be higher, the higher is aggregate demand for bills, as shown by the total amount bid, and lower, the greater the quantity of bills issued. Profitability was reduced when there was a large stock of similar bills outstanding in the market. These results suggest that bidding behavior was inconsistent with the assumption that the value of the bills was strictly common to all bidders; bidding behavior seems to have been 
influenced by considerations of desired inventory maintenance and the transaction costs of trading in the secondary market.

- Bidder-specific effects were significant. Notably, a bidder that submitted a relatively large volume of bids on average earned lower profits, but a bidder that held a relatively large stock of bills bid more aggressively and earned higher profits. These regularities again suggest that bidders were concerned to maintain a target quantity of bills in their portfolios.

- The average price bid in an auction was normally influenced in approximately equal measure by the expected post-auction secondary market price of the bills to be issued, and the secondary market price of old bills that obtained at the time bids were formulated, in addition to the expected cut-off price. Thus, prices bid seemed to reflect a mixture of 'buy and sell' and 'buy and hold' strategies.

In conclusion, Pakistan seems to have been able to establish a successful primary market for treasury bills, and to develop an adequately liquid secondary market within the period considered here. The Pakistani experience gives credence to the effectiveness of auctions as a mechanism to determine a market-based price and allocation even under conditions of asymmetric market power and considerable uncertainty. 


\section{REFERENCES}

Back, K., and J. Zender, "Auctions of Divisible Goods: On the Rationale for the Treasury Experiment," Review of Financial Studies 6(4), 1993, pp. 733-764.

Bartolini, Leonardo, and Carlo Cottarelli, "Treasury Bill Auctions: Issues and Uses," IMF Working Paper WP/94/135, November 1994, Washington D.C.

Bikhchandani, Sushil, and Chi-fu Huang, "Auctions with Resale Markets: An Exploratory Model of Treasury Bill Markets," Review of Financial Studies, Vol. 2 No. 3, 1993, pp. $311-339$.

Bikhchandani, Sushil, and Chi-fu Huang, "The Economics of Treasury Securities Markets," Journal of Economic Perspectives, Vol. 7 No. 3, 1993, pp. 117-134.

Bolton, Steven "Treasury Bill Auction Procedures: An Empirical Investigation," Journal of Finance, 1973, pp. 577-585.

Cammack, Elizabeth B., "Evidence on Bidding Strategies and the Information Contained in Auctions," Journal of Political Economy, Vol. 99, 1979, pp. 100-130.

Carracedo, Montserrat Ferré, and Peter Dattels, "Survey of Public Debt Management Frameworks in Selected Countries," in Sundararajan, V., Peter Dattels, and Hans J. Blommestein (Eds.), Coordinating Public Debt and Monetary Management, International Monetary Fund, 1997, Washington D.C.

Das, Sanjiv Ranjan, and Rangarajan K. Sundaram, "Auction Theory: A Summary with Applications to Treasury Markets," NBER Working Paper No. 5873, January 1997, Cambridge MA.

Feldman, Robert A., and Vincent Reinhart, "Auction Format Matters: Evidence on Bidding Behavior and Seller Revenue,: IMF Working Paper WP/95/47, May 1995, Washington D.C.

Khan, Shahrukh Rafi, and Safiya Aftab, "Assessing the Impact of Financial Reforms on Pakistan" Economy," Pakistan Journal of Applied Economics, Vol. X No. 1\&2, 1994, pp. 99-116.

McAfee, R.P., and J. McMillan, "Auctions and Bidding," Journal of Economic Literature, 1987, pp. 699-738.

Milgrom, Paul, "Auctions and Bidding: A Primer," Journal of Economic Perspectives, Vol. 3 No. 3, 1989, pp. 3-22.

Nautz, D., and E. Wolfstetter, "Bid Shading and Risk Aversion in Multi-unit Auctions with Many Bidders," Economic Letters, Vol. 56, 1997, pp. 195-200. 
Pesaran, M. Hashem, and Richard J. Smith, "A Generalized $\mathrm{R}^{2}$ Criterion for Regression Models Estimated by the Instrumental Variables Method," Econometrica, Vol. 62, No. 3, May 1994, pp. 705-710.

Phillips, Peter C. B., and Bruce E. Hansen, "Statistical Inference in Instrumental Variables Regression with I(1) Processes," Review of Economic Studies, 1989, pp. 99-125.

Simon, David P., "Markups, Quantity Risk, and Bidding Strategies in Treasury Coupon Auctions," Journal of Financial Economics, 35, 1994, pp. 43-62.

Spindt, Paul A., and Richard W. Stolz, "Are US Treasury Bills Underpriced in the Primary Market," Journal of Banking and Finance, 16, 1992, pp. 891-908.

U1 Haque, Nadeem, "Financial Market Reform in Pakistan," The Pakistan Development Review, 36:4 Part II, Winter 1997, pp. 839-854.

Umlauf, Steven R., "An Empirical Study of the Mexican Treasury Bill Auction," Journal of Financial Economics, 33, 1993, pp. 313-340.

Viswanathan, S. and James J.D. Wang, "Auctions with When-Issued Trading: A Model of the U.S. Treasury Markets," unpublished working paper, 1999.

White, Halbert, "A Heteroskedasticity-Consistent Covariance Matrix and a Direct test for Heteroskedasticity," Econometrica, 48, 1980, pp. 721-746.

Wilson, R., "Auctions for Shares," Quarterly Journal of Economics, 93, 1979, pp. 675-689. 


\section{Summary of Variables Employed 1/}

Log of weighted average price bid by auction $2 /$

$A W M P$

Log of weighted average price bid by bidder, by auction $2 / W M P$

$\mathrm{Log}$ of bill bid price following auction $2 /$

Log of bill offer price before auction $2 /$

Spread between bill bid-offer $\log$ prices before auction

Log of cut-off price $2 /$

Log of cut-off price in preceding auction

Standard deviation of price bid by bidder, by auction

Standard deviation of price bid by auction

Standard deviation of bill offer price in five days before auction

Log of total volume bid by auction

Log of volume bid by bidder, by auction

Log of total winning volume bid by auction

Log of volume winning bid by bidder, by auction

Ratio of winning volume to total volume bid by auction

Ratio of winning volume to total volume bid by bidder, by auction

Difference between win ratio by bidder and aggregate win ratio

Number of bidders in auction

Number of winning bidders in auction

Number of bids in auction

Number of winning bids in auction

\section{$T B B I D(+1)$}

TBOFF $(-1)$

TBOFF(-1)-TBBID(-1)

$\mathrm{CO}$

$C O(-1)$

$S D P B I D$

$A S D P B I D$

SDTBOFF

$A V$

V

$A W$

$W$

$A W / A V$

$W / V$

$(W / V)-(A W / A V)$

$A N B D R$

$A N W N R$

$A N B D$

$A N W N$
0.049

0.021

0.648

0.866

0.342

0.087

448.241

0.198

0.386

0.203

9.297

5.537

8.250

2.303

0.523

0.474

$-0.049$

24.774

17.187

126.541

60.456
0.326

0.474

0.801

0.537

0.237

0.444

0.923

0.157

0.159

0.212

0.655

1.318

1.934

4.587

0.268

0.399

0.295

6.005

8.310

57.571

42.225

1/ Sample excluding singleton bids and period of fixed cut-off price. Number of observations $=764$.

$2 /$ Normalized by log of cut-off price in preceding auction. 